\title{
Organic molecular composition of marine aerosols over the Arctic Ocean in summer: contributions of primary emission and secondary aerosol formation
}

\author{
P. Q. Fu ${ }^{1,2}$, K. Kawamura ${ }^{2}$, J. Chen ${ }^{3}$, B. Charrière ${ }^{4}$, and R. Sempéré ${ }^{4}$ \\ ${ }^{1}$ State Key Laboratory of Atmospheric Boundary Layer Physics and Atmospheric Chemistry, Institute of Atmospheric \\ Physics, Chinese Academy of Sciences, Beijing 100029, China \\ ${ }^{2}$ Institute of Low Temperature Science, Hokkaido University, Sapporo 060-0819, Japan \\ ${ }^{3}$ SKLEG, Institute of Geochemistry, Chinese Academy of Sciences, Guiyang 550002, China \\ ${ }^{4}$ Aix-Marseille Université, Mediterranean Institute of Oceanography (MIO), 13288, Marseille, Cedex 9; Université du Sud \\ Toulon-Var, MIO, CNRS/INSU, MIO UMR 7294, France
}

Correspondence to: P. Q. Fu (fupingqing@mail.iap.ac.cn)

Received: 30 June 2012 - Published in Biogeosciences Discuss.: 8 August 2012

Revised: 1 December 2012 - Accepted: 19 December 2012 - Published: 1 February 2013

\begin{abstract}
Organic molecular composition of marine aerosol samples collected during the MALINA cruise in the Arctic Ocean was investigated by gas chromatography/mass spectrometry. More than 110 individual organic compounds were determined in the samples and were grouped into different compound classes based on the functionality and sources. The concentrations of total quantified organics ranged from 7.3 to $185 \mathrm{ng} \mathrm{m}^{-3}$ (mean $47.6 \mathrm{ng} \mathrm{m}^{-3}$ ), accounting for $1.8-$ $11.0 \%(4.8 \%)$ of organic carbon in the marine aerosols. Primary saccharides were found to be dominant organic compound class, followed by secondary organic aerosol (SOA) tracers formed from the oxidation of biogenic volatile organic compounds (VOCs) such as isoprene, $\alpha$-pinene and $\beta$-caryophyllene. Mannitol, the specific tracer for airborne fungal spores, was detected as the most abundant organic species in the samples with a concentration range of 0.052 $53.3 \mathrm{ng} \mathrm{m}^{-3}\left(9.2 \mathrm{ng} \mathrm{m}^{-3}\right)$, followed by glucose, arabitol, and the isoprene oxidation products of 2-methyltetrols. Biomass burning tracers such as levoglucosan are evident in all samples with trace levels. On the basis of the tracer-based method for the estimation of fungal-spore $\mathrm{OC}$ and biogenic secondary organic carbon (SOC), we estimate that an average of $10.7 \%$ (up to $26.2 \%$ ) of the OC in the marine aerosols was due to the contribution of fungal spores, followed by the contribution of isoprene SOC (mean $3.8 \%$ ) and $\alpha$-pinene SOC $(2.9 \%)$. In contrast, only $0.19 \%$ of the OC was due to
\end{abstract}

the photooxidation of $\beta$-caryophyllene. This study indicates that primary organic aerosols from biogenic emissions, both from long-range transport of mid-latitude aerosols and from sea-to-air emission of marine organics, as well as secondary organic aerosols formed from the photooxidation of biogenic VOCs are important factors controlling the organic chemical composition of marine aerosols in the Arctic Ocean.

\section{Introduction}

Organic aerosols are ubiquitous in the marine atmosphere. Given the ocean's extension, marine organic aerosols have received increasing attention because they constitute one of the most important natural aerosol systems at a global level (O'Dowd and de Leeuw, 2007; Langmann et al., 2008). Marine organic aerosols play major roles in the environmental issues related to global and regional climate, chemistry of the atmosphere, and biogeochemical cycling of nutrients such as carbon and nitrogen (O'Dowd and de Leeuw, 2007). For example, they influence solar irradiation directly by backscattering solar irradiation and indirectly by forming cloud condensation nuclei (CCN) (Meskhidze and Nenes, 2006).

To fully understand the sources and molecular composition of marine organic aerosols is necessary to evaluate their impacts on climate. Marine organic aerosols 
comprise primary organic aerosol (POA) and secondary organic aerosol (SOA). Primary marine organic aerosols can be produced from the interaction of wind with the ocean surface and results in the mechanical production of sea spray aerosols (Rinaldi et al., 2010). The best-known precursor of marine POA is dimethyl sulphide (DMS) that is produced biogenically in the ocean. Sea spray aerosols are assumed to enrich in organic matter when the marine surface is characterized by high biological activities (O'Dowd et al., 2004). A recent study (Schmitt-Kopplin et al., 2012) provides evidence that marine surface water via bubble bursting processes can produce a significant fraction of primary organic aerosols that typically contain homologous series of oxo-, hydroxy-, methoxy-, branched fatty acids and mono-, di- and tricarboxylic acids as well as monoterpenes and sugars.

The atmospheric oxidation of volatile organic compounds (VOCs) emitted from the ocean can form SOA (O'Dowd and de Leeuw, 2007). Traditionally, the most studied SOA component in the marine boundary layer (MBL) is methanesulfonic acid (MSA), which is formed from the oxidation of DMS. Other components such as organosulfates (sulfate esters of $\mathrm{C}_{9}-\mathrm{C}_{13}$ hydroxyl carboxylic acids) can be considered as marine SOA tracers for the oxidation of unsaturated fatty acids derived from marine algae (Claeys et al., 2010). Meskhidze and Nenes (2006) proposed that SOA formation from the oxidation of phytoplankton-derived isoprene can affect the chemical composition of marine $\mathrm{CCN}$ and influence cloud droplet number. Laboratory experiments (Ekström et al., 2009) have shown that 2-methyltetrols, tracers for isoprene SOA (Claeys et al., 2004), and related isoprene oxidation products can increase $\mathrm{CCN}$ levels in the pristine marine atmosphere that is limited in CCN. In addition to the oceanic emission of isoprene, recent shipboard measurements over the South Atlantic Ocean have provided the evidence for marine production of monoterpenes (Yassaa et al., 2008). However, recent modeling studies suggested that the oceanic isoprene and monoterpene sources are not significant enough to control marine organic aerosols (Spracklen et al., 2008; Arnold et al., 2009; Gantt et al., 2009; Anttila et al., 2010). For example, Myriokefalitakis et al. (2010) proposed that the annual global marine SOA from isoprene and monoterpene oxidation was minor $\left(0.1 \mathrm{Tg} \mathrm{yr}^{-1}\right)$, compared to those from the oxidation of DMS $\left(4 \mathrm{Tg} \mathrm{yr}^{-1}\right)$ and marine amines $\left(1 \mathrm{Tg} \mathrm{yr}^{-1}\right)$.

Despite considerable advances in primary and secondary marine aerosol studies during the last decade, the chemical nature of marine organic aerosols remains poorly understood, due to their diverse sources and formation mechanisms (O'Dowd and de Leeuw, 2007). Marine organic aerosols are influenced not only by oceanic emissions of primary aerosols and SOA precursors, but also by continental emissions through long-range atmospheric transport. So far, field measurements concerning organic molecular compositions of marine aerosols are limited (e.g., Simoneit et al., 1991; Simoneit et al., 2004b; Fu et al., 2011). In particular, lit- tle is known about the abundances of biogenic SOA tracers from the oxidation of isoprene (e.g., 2-methyltetrols) and $\alpha / \beta$-pinene (e.g., pinonic and pinic acids) in the MBL (Fu et al., 2011), especially in the polar regions. During the polar sunrise season, the Arctic atmosphere can serve as a unique photochemical reactor influenced by marine-derived particles from the Arctic Ocean and continent-derived particles and their precursors from the mid-latitudes in Eurasia or North America (Barrie, 1986; Quinn et al., 2007). During summer, the Arctic atmosphere is isolated from lower latitudes by the polar front (Iziomon et al., 2006). Because climate change is proceeding fastest in the high latitudes (Law and Stohl, 2007), and the Arctic Ocean waters could be an important source of Arctic aerosols in summer, there is an increasing demand for better understanding the molecular characteristics and the sources of biogenic POA and SOA in the summertime Arctic atmosphere.

The objective of this study is to investigate the chemical speciation of both POA and SOA in the MBL over the southern Beaufort Sea, Canadian Arctic. More than 110 organic compounds including aliphatic lipids, anhydrosugars, primary saccharides, lignin and resin acids, aromatic acids, polyacids, sterols, as well as polar organic tracer (e.g., 2methyltetrols, pinic acid, and $\beta$-caryophyllinic acid) for the photooxidation of biogenic VOCs have been detected in the marine aerosols. Their possible sources, formation processes, and the contributions of different organic compounds to organic carbon (OC) are also discussed.

\section{Materials and methods}

\subsection{Sample collection}

The France-Canada-USA joint Arctic campaign, MALINA, was conducted in the southern Beaufort Sea, Canadian Arctic, in summer 2009. Total suspended particulate (TSP) samples $(n=10)$ were collected on a two-three day basis using a high volume air sampler (Kimoto AS-810B) aboard the icebreaker CCGS Amundsen on 3-25 August 2009. One field blank filter was performed by placing it in the sampler for less than one minute without turning on the pump. All samples were collected onto pre-combusted $\left(450^{\circ} \mathrm{C}\right.$ for $\left.6 \mathrm{~h}\right)$ quartz fiber filters $(20 \times 25 \mathrm{~cm}$, Pallflex 2500QAT-UP). The pump of the air sampler was switched on/off using a wind speed $\left(>5 \mathrm{~m} \mathrm{~s}^{-1}\right)$ and wind sector $\left( \pm 60^{\circ}\right)$ controller system to avoid any potential contamination from the ship exhaust. Before the sampling, filter was placed in a pre-combusted $\left(450^{\circ} \mathrm{C}\right.$ for $\left.6 \mathrm{~h}\right)$ glass jar with a Teflon-lined cap during the transport and storage. After the sampling, the filter was recovered into the glass jar, transported to the laboratory and stored at $-20^{\circ} \mathrm{C}$ prior to analysis. 


\subsection{Extraction and derivatization}

For each sample, a filter aliquot (ca. $25 \mathrm{~cm}^{2}$ ) was cut into pieces and extracted three times with dichloromethane/methanol $(2: 1 ; \mathrm{v} / \mathrm{v})$ under ultrasonication for $10 \mathrm{~min}$. The solvent extracts were filtered through quartz wool packed in a Pasteur pipette, concentrated by the use of a rotary evaporator, and then blown down to dryness with pure nitrogen gas. The extracts were then reacted with $50 \mu \mathrm{L}$ of N,O-bis-(trimethylsilyl)trifluoroacetamide (BSTFA) with $1 \%$ trimethylsilyl chloride and $10 \mu \mathrm{L}$ of pyridine at $70^{\circ} \mathrm{C}$ for $3 \mathrm{~h}$. After reaction, the derivatives were diluted by the

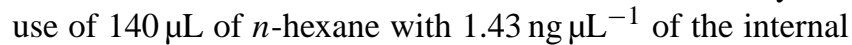
standard $\left(\mathrm{C}_{13} n\right.$-alkane) prior to gas chromatography/mass spectrometry (GC/MS) injection.

\subsection{Gas chromatography/mass spectrometry}

GC/MS analyses were performed on a Hewlett-Packard model 6890 GC coupled to Hewlett-Packard model 5973 mass-selective detector (MSD). The GC was equipped with a split/splitless injection and a DB-5MS fused silica capillary column $(30 \mathrm{~m} \times 0.25 \mathrm{~mm}$ in diameter, $0.25 \mu \mathrm{m}$ film thickness) with the $\mathrm{GC}$ oven temperature programmed from $50{ }^{\circ} \mathrm{C}(2 \mathrm{~min})$ to $120{ }^{\circ} \mathrm{C}$ at $15^{\circ} \mathrm{C} \mathrm{min}^{-1}$ and then to $300^{\circ} \mathrm{C}$ at $5^{\circ} \mathrm{Cmin}^{-1}$ with a final isotherm hold at $300^{\circ} \mathrm{C}$ for $16 \mathrm{~min}$. Helium was used as the carrier gas at a flow rate of $1.0 \mathrm{~mL} \mathrm{~min}^{-1}$. The sample was injected on a splitless mode with the injector temperature at $280^{\circ} \mathrm{C}$. The mass spectrometer was operated in the electron ionization (EI) mode at $70 \mathrm{eV}$ and scanned in the $m / z$ range 50-650. Data were acquired and processed with the ChemStation software. GC/MS response factors were determined using authentic standards. For some biogenic SOA tracers whose standards are not commercially available, their concentrations were estimated by some surrogates (Fu et al., 2010). Recovery experiments were performed by spiking a certain amount of authentic standards onto pre-combusted quartz fiber filters and were analyzed like real samples. Recoveries of all the standards were better than $80 \%$ expect for polyacids and pinonic acid, whose recoveries were around $60 \%$ (Fu et al., 2009a; 2010). The field and the laboratory blank filters were also analyzed by the procedure described above for quality assurance. The results showed contamination levels are less than $5 \%$ of real samples for any species detected. All the data reported here were corrected for the field blank.

\subsection{Analysis for OC}

Organic carbon (OC) and elemental carbon (EC) were determined using a Sunset Lab carbon analyzer, following the Interagency Monitoring of Protected Visual Environments (IMPROVE) thermal evolution protocol and assuming carbonate carbon in the sample to be negligible (Wang et al., 2005a). In brief, an aliquot $(\Phi 14 \mathrm{~mm})$ of quartz fiber filter was punched for each sample. The punched filter was placed in a quartz boat inside the thermal desorption chamber of the analyzer, and then stepwise heating was applied. The analytical errors in triplicate analysis were within $10 \%$, and the limits of detection (LOD) were $0.2 \mu \mathrm{g} \mathrm{cm}^{-2}$ for both OC and EC. The levels of EC in the samples were generally below the LOD and thus were not reported here.

\section{Results and discussion}

\subsection{Meteorological conditions and air-mass back trajectory analysis}

During sample collection, the ambient temperatures ranged from $-1.5^{\circ} \mathrm{C}$ to $9.2^{\circ} \mathrm{C}$ with an average of $3.0^{\circ} \mathrm{C}$. The weather conditions during the cruise were mostly cloudy and occasionally foggy with rare sunny conditions (Table 1), while there were no rain/snow events during the sampling period. In order to determine where tropospheric air arrived to the ship during sampling periods for each aerosol sample, air-mass back trajectory analyses were conducted using the NOAA Hybrid Single-Particle Lagrangian Integrated Trajectory (HYSPLIT) model (http:www.arl.noaa. gov./ready/hysplit4.html). The trajectories were calculated from the start-to-end points every $3 \mathrm{~h}$ of each sampling period at altitudes of 50, 100, and $200 \mathrm{~m}$. As shown in Fig. 1, air masses mostly came from the west and then passed over the Arctic Ocean to the ship during 3-11 August when the samples of QFF3352, QFF3354 and QFF3355 were collected. QFF3358-3360 also showed similar trajectories, which were mainly from the west direction. However, QFF3356 and QFF3357, as well as the last two samples (QFF3361 and QFF3362), were collected when the air masses mainly originated from the northeast, east and southeast directions. This is especially true for the last sample (QFF3362), which showed air masses were transported from northern Canada, indicating an influence of continental aerosols.

\subsection{Organic compounds}

Homologues of ten organic compound classes, i.e., nalkanes, fatty acids, fatty alcohols, sugar compounds, lignin and resin acids, sterols, phthalate esters, hydroxy-/polyacids, aromatic acids, and biogenic SOA tracers, were detected in the marine aerosols with total concentration ranges of 7.3$185 \mathrm{ng} \mathrm{m}^{-3}$ (mean $47.6 \mathrm{ng} \mathrm{m}^{-3}$ ). Table $\mathrm{S} 1$ presents the concentrations of more than 110 organic compounds detected in this study. Figure 2 shows a typical GC/MS trace (Total Ion Current, TIC) for the major resolved organic components of total aerosol extracts. Among the identified organic compounds, sugar compounds, fatty acids and biogenic SOA tracers are the major compound classes, while the others are relatively minor (Fig. 3). Mannitol, a specific tracer for airborne fungal spores, was (on average) found to be the most abundant single compound, followed by glucose, arabitol, 


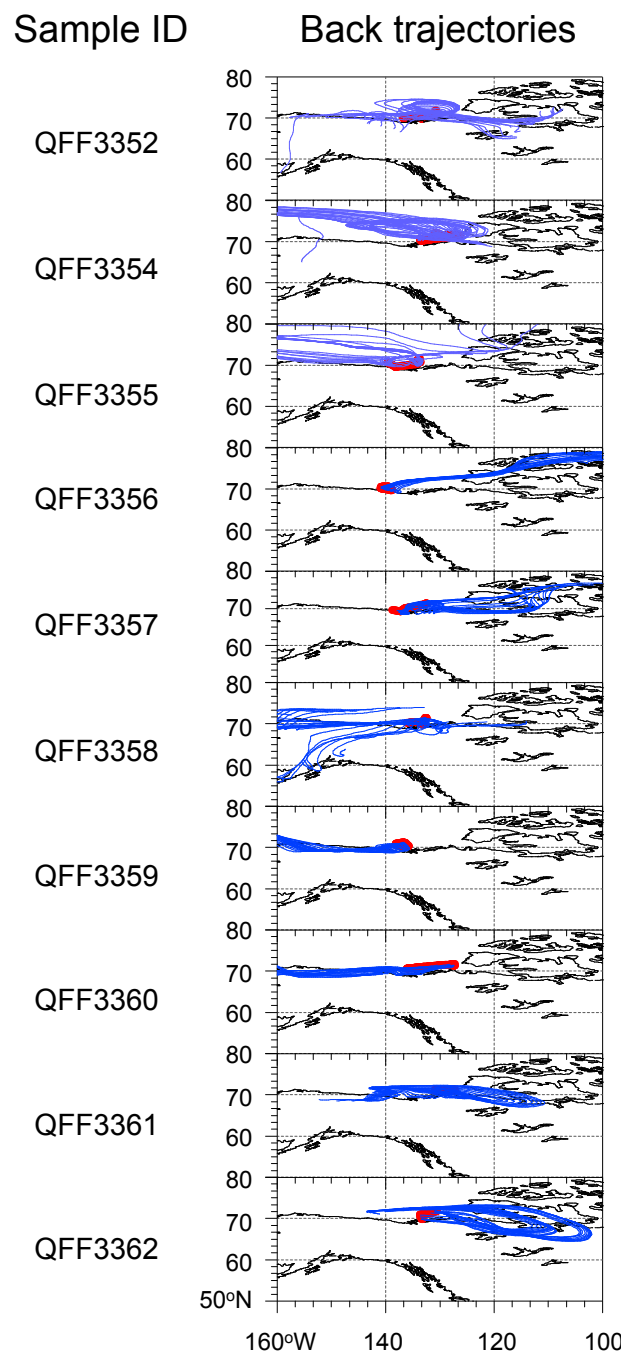

\section{Cruise tracks}

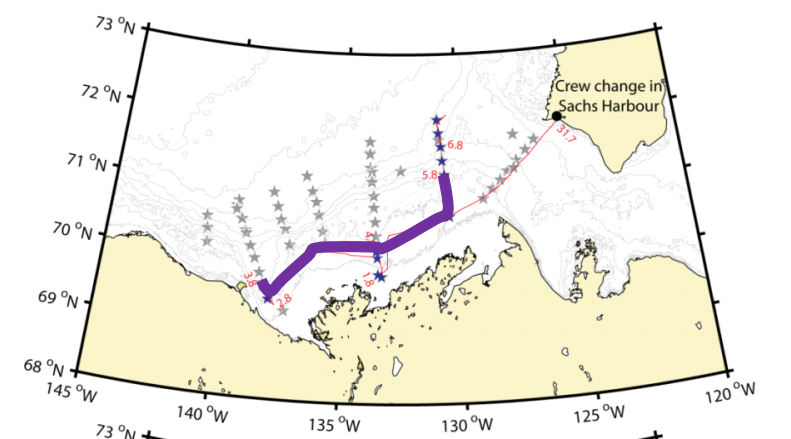

Sample ID
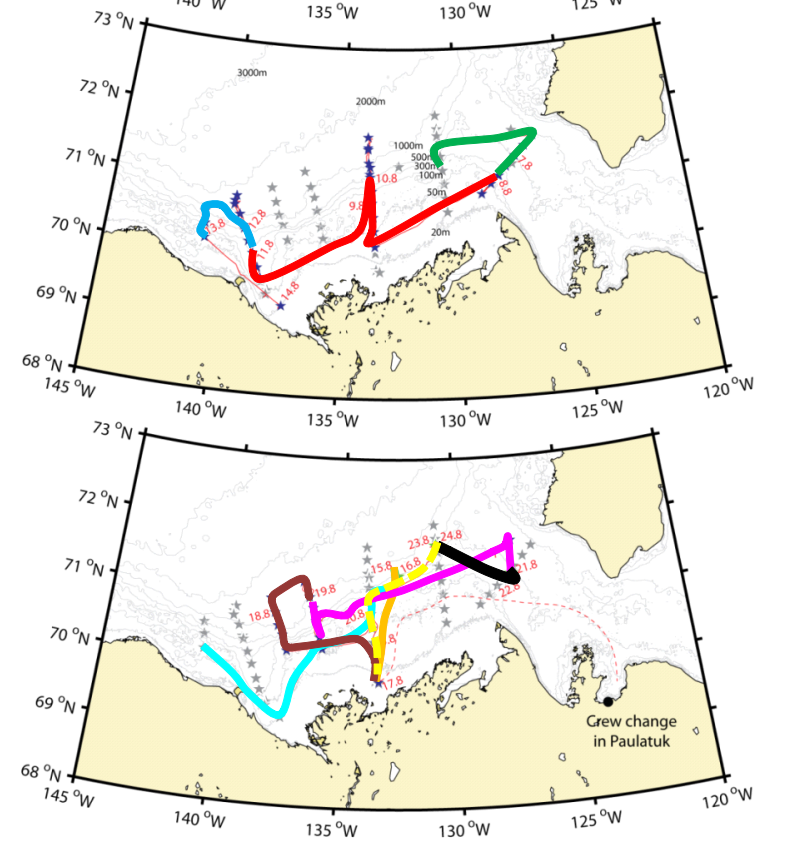

3357

3358

3359

3360

3361

3362

Fig. 1. Five-day air mass back trajectories for each sample collected in the southern Beaufort Sea, Canadian Arctic, during the MALINA campaign are shown on the left side; cruise tracks are presented in red. Enlarged cruise tracks for each sample are shown on the right side.

and di-(2-ethylhexyl)phthalate (Table S1); such a pattern is different from those reported in urban aerosols (e.g., Wang et al., 2006), which were dominated by biomass burning tracers and phthalates.

Generally, much higher levels of organics were found in the middle (13-15, August, QFF3357) and at the end (23-25, August, QFF3362) of the campaign (Fig. 3) than other periods. This trend is similar to the temporal variations of $\mathrm{OC}$ contents (Table 1) and dicarboxylic acids in the same sample set (Kawamura et al., 2012). OC in the marine aerosols ranged from $0.11-2.93 \mu \mathrm{gC} \mathrm{m}^{-3}$ (mean $0.56 \mu \mathrm{gC} \mathrm{m}^{-3}$ ), being in accordance with those $\left(0.11-1.4 \mu \mathrm{gC} \mathrm{m}^{-3}\right)$ reported in the northern Indian Ocean (Neusüß et al., 2002), and those $\left(0.06-1.7 \mu \mathrm{gC} \mathrm{m}^{-3}\right.$, mean $\left.0.58 \mu \mathrm{gC} \mathrm{m}^{-3}\right)$ in marine aerosols collected during a round-the-world cruise in the low to midlatitudes in the Northern Hemisphere (Fu et al., 2011). The highest level of OC was found in QFF3357 $\left(2.93 \mathrm{ng} \mathrm{m}^{-3}\right)$ that was collected near the seashore (Table 1 and Fig. 1), suggesting a terrestrial input. QFF3362 also contained a relatively high level of OC.

\subsubsection{Biomass burning tracers}

Biomass burning is an important source of atmospheric gases and particles on a regional and global scale. In the Arctic region, biomass-burning aerosols are enhanced in winterspring due to long-range atmospheric transport from midlatitudes in Eurasia and North America (Stohl et al., 2007; Fu et al., 2009a). A recent aircraft observation of forest fires in the Siberia in summer found that the fire plumes can transport toward the Arctic (Paris et al., 2009). Levoglucosan, which is produced in large quantities during pyrolysis of cellulose, is considered as a key tracer for biomass burning (Simoneit, 2002). In the present study, concentrations of levoglucosan ranged from 0.01 to $0.93 \mathrm{ng} \mathrm{m}^{-3}\left(0.37 \mathrm{ng} \mathrm{m}^{-3}\right)$, representing 


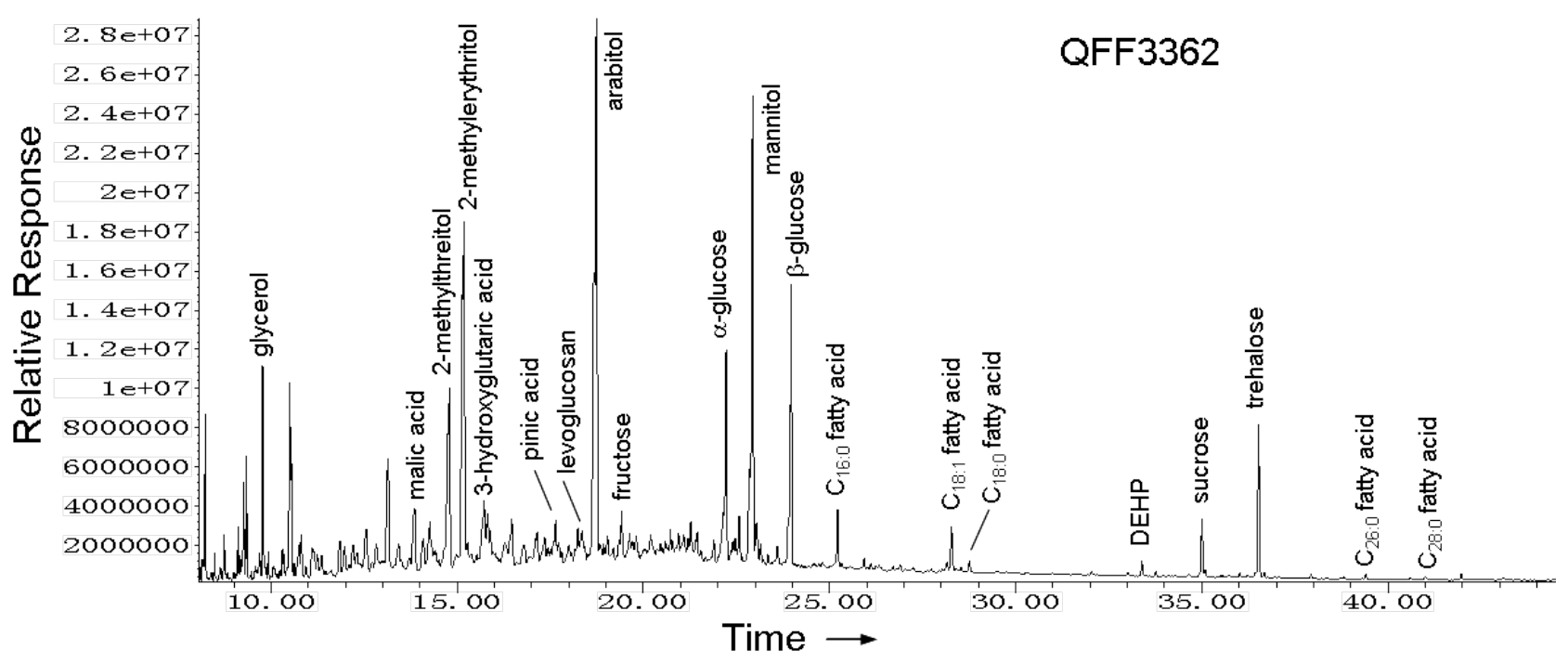

Fig. 2. A typical GC/MS trace (total ion current, TIC) for a total extract (trimethylsilyl (TMS) derivatized) of the aerosol sample (QFF3362) collected in the Arctic Ocean. For abbreviations, see Table S1.

Table 1. Bulk and organic molecular data for marine aerosol samples collected during the MALINA cruise in 2009. Concentrations for organic species are presented in $\mathrm{ng} \mathrm{m}^{-3}$.

\begin{tabular}{|c|c|c|c|c|c|c|c|c|c|c|c|c|c|c|c|c|c|}
\hline \multirow{2}{*}{$\begin{array}{l}\text { Sample } \\
\text { No. }\end{array}$} & \multirow{2}{*}{$\begin{array}{l}\text { Sample } \\
\text { ID }\end{array}$} & \multirow{2}{*}{$\begin{array}{l}\text { Sample } \\
\text { periods }\end{array}$} & \multirow{2}{*}{$\begin{array}{l}\text { Cloud } \\
\text { cover }^{\mathrm{a}}\end{array}$} & \multirow{2}{*}{$\begin{array}{c}\text { Origin } \\
\text { of air mass }{ }^{b}\end{array}$} & \multirow{2}{*}{$\begin{array}{c}\mathrm{Chl} a \\
\left(\mu \mathrm{g} \mathrm{L}^{-1}\right)\end{array}$} & \multirow{2}{*}{$\begin{array}{c}\mathrm{OC} \\
\left(\mathrm{ug} \mathrm{m}^{-3}\right)\end{array}$} & \multicolumn{3}{|c|}{ n-Alkanes } & \multicolumn{3}{|c|}{$n$-Fatty acids } & \multicolumn{2}{|c|}{$n$-Alcohols } & \multirow[b]{2}{*}{ Levo $^{d}$} & \multirow[b]{2}{*}{ Mannitol $^{\mathrm{e}}$} & \multirow[b]{2}{*}{ 2-MT } \\
\hline & & & & & & & $\begin{array}{c}\text { LMW } \\
\left(\mathrm{C}_{18-24}\right) \\
\end{array}$ & $\begin{array}{c}\text { HMW } \\
\left(\mathrm{C}_{25-34}\right) \\
\end{array}$ & $\mathrm{CPI}^{\mathrm{c}}$ & $\begin{array}{c}\text { LMW } \\
\left(\mathrm{C}_{8-23}\right)\end{array}$ & $\begin{array}{c}\text { HMW } \\
\left(\mathrm{C}_{24-32}\right) \\
\end{array}$ & $\mathrm{C}_{18: n} / \mathrm{C}_{18: 0}$ & $\begin{array}{c}\text { LMW } \\
\left(\mathrm{C}_{12-23}\right)\end{array}$ & $\begin{array}{c}\text { HMW } \\
\left(\mathrm{C}_{24-30}\right)\end{array}$ & & & \\
\hline 1 & QFF3352 & 3-5 Aug & MC-O & $\mathrm{AK} / \mathrm{AO}$ & $0.40 \pm 0.23$ & 0.30 & 0.05 & 0.17 & 1.9 & 0.87 & 0.16 & 0.5 & 0.27 & 0.16 & 0.67 & 3.2 & 0.18 \\
\hline 2 & QFF3354 & 5-8 Aug & MC-O, fog & $\mathrm{AO}$ & $1.97 \pm 3.74$ & 0.36 & 0.17 & 0.47 & 1.6 & 2.3 & 0.33 & 0.2 & 1.1 & 0.28 & 0.93 & 0.05 & 0.31 \\
\hline 3 & QFF3355 & 8-11 Aug & MC-O & $\mathrm{AO}$ & $0.09 \pm 0.035$ & 0.36 & 0.19 & 0.33 & 1.7 & 1.5 & 0.19 & 0.1 & 0.76 & 0.18 & 0.67 & 0.13 & 0.21 \\
\hline 4 & QFF3356 & 11-13 Aug & MC-O & $\mathrm{NC}$ & $1.46 \pm 1.34$ & 0.25 & 0.15 & 0.29 & 2.3 & 2.8 & 0.13 & 1.4 & 2.9 & 0.70 & 0.14 & 1.7 & 0.57 \\
\hline 5 & QFF3357 & 13-15 Aug & MC-O, fog & $\mathrm{NC} / \mathrm{AO}$ & $1.64 \pm 1.33$ & 2.93 & 1.1 & 3.4 & 1.5 & 10.7 & 1.2 & 1.8 & 5.3 & 3.1 & 0.33 & 53.3 & 1.22 \\
\hline 6 & QFF3358 & 15-17 Aug & PC-O & $\mathrm{AO}$ & $0.98 \pm 1.00$ & 0.11 & 0.07 & 0.06 & 1.7 & 0.86 & 0.03 & 0.9 & 1.1 & 0.11 & 0.06 & 0.29 & 0.20 \\
\hline 7 & QFF3359 & 17-19 Aug & $\mathrm{O}$ & $\mathrm{AO}$ & $0.075 \pm 0.003$ & 0.23 & 0.04 & 0.14 & 1.7 & 0.89 & 0.05 & 1.3 & 0.33 & 0.19 & 0.01 & 4.0 & 0.15 \\
\hline 8 & QFF3360 & 19-21 Aug & MC-O & $\mathrm{AO}$ & $0.072 \pm 0.02$ & 0.20 & 0.06 & 0.08 & 1.8 & 1.4 & 0.06 & 0.8 & 0.46 & 0.73 & 0.02 & 5.0 & 0.06 \\
\hline 9 & QFF3361 & 21-23 Aug & C-O & $\mathrm{NC} / \mathrm{AO}$ & - & 0.25 & 0.07 & 0.17 & 2.1 & 2.0 & 0.11 & 0.6 & 0.55 & 0.99 & 0.03 & 8.6 & 0.37 \\
\hline 10 & QFF3362 & 23-25 Aug & $\mathrm{O}$, fog & $\mathrm{NC}$ & $0.11 \pm 0.04$ & 0.65 & 0.34 & 0.80 & 7.0 & 9.4 & 0.95 & 3.9 & 4.0 & 3.0 & 0.80 & 15.5 & 28.4 \\
\hline
\end{tabular}

${ }^{\text {a }}$ C: clear (>0 to $5 \%$ ); PC: partly cloudy (5 to $50 \%$ ); MC: mostly cloudy (50 to $95 \%$ ); O: overcast (95-100\%).

$\mathrm{b}$ Primary source regions for air-mass back trajectories: Arctic Ocean (AO), Alaska (AK), northern Canada (NC).

${ }^{c}$ CPI, carbon preference index: $\left(\mathrm{C}_{21}+\mathrm{C}_{23}+\mathrm{C}_{25}+\mathrm{C}_{27}+\mathrm{C}_{29}+\mathrm{C}_{31}+\mathrm{C}_{33}\right) /\left(\mathrm{C}_{22}+\mathrm{C}_{24}+\mathrm{C}_{26}+\mathrm{C}_{28}+\mathrm{C}_{30}+\mathrm{C}_{32}+\mathrm{C}_{34}\right)$ for $n$-alkanes.

${ }^{\mathrm{d}}$ Levo: levoglucosan, a biomass-burning tracer (Simoneit, 2002).

e Mannitol: a fungal-spore tracer (Bauer et al., 2008).

f 2-MT: 2-methyltetrols, the sum of 2-methylthreitol and 2-methylerythritol, which are isoprene SOA tracers (Claeys et al., 2004).

a background level over the southern Beaufort Sea, Canadian Arctic. These values are similar to those $\left(0.003-1.1 \mathrm{ng} \mathrm{m}^{-3}\right)$ found in the Canadian high Arctic aerosols collected at Alert (Fu et al., 2009a), where the level of levoglucosan was found to be higher in winter than in spring. The isomers of levoglucosan, galactosan and mannosan were also detected in the samples (Table S1). These anhydrosugars were also detected in aerosols collected over the open oceans (Fu et al., 2011). Such a low level of levoglucosan in the marine aerosols over the Arctic Ocean should be explained by both wet/dry depositions and atmospheric dilution of aerosol particles during long-range transport. Further, levoglucosan may be possibly removed by photodegradation through the reaction with free radicals such as $\mathrm{OH}$ (Hoffmann et al., 2010).

Dehydroabietic acid, a specific biomass-burning tracer of conifer resin, is often detected in urban, rural and marine aerosols (Simoneit et al., 2004b; Fu et al., 2011). The concen- tration ranges of dehydroabietic acid were $0.02-0.65 \mathrm{ng} \mathrm{m}^{-3}$ with an average of $0.14 \mathrm{ng} \mathrm{m}^{-3}$. These values are higher than those $\left(0.002-0.033 \mathrm{ng} \mathrm{m}^{-3}\right)$ in the high Arctic aerosols that were collected during winter-spring (Fu et al., 2009a). This suggests that the influence of wildfires in the boreal conifer forests in Siberia and North America on the Arctic atmosphere may be more important during summer-autumn than winter-spring. Lignin is a wood polymer and, upon burning, yields phenolic acids. 4-Hydroxybenzoic acid is produced by burning of grasses and other non-woody vegetation, whereas vanillic acid is produced from both softwood and hardwood (Simoneit, 2002). 3,4-Dihydroxybenzoic acid (protocatechuic acid) is an antioxidant that contains a polyphenolic structure. These phenolic compounds have been reported in smoke particles and ambient aerosols (Simoneit, 2002). They were detected at trace levels in the present study (Table S1), which are 1-2 orders of magnitude lower than those reported 


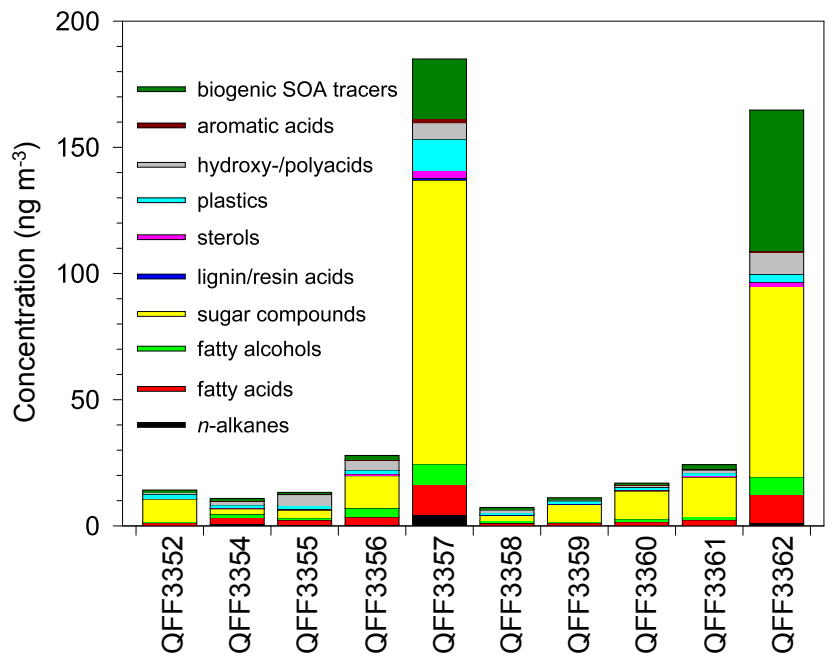

Fig. 3. Chemical compositions of organic compounds in the summertime marine aerosols collected during the MALINA campaign.

in coastal marine aerosols $\left(0.5-9.0 \mathrm{ng} \mathrm{m}^{-3}\right.$ ) (Simoneit et al., 2004b).

$\beta$-Sitosterol was also detected in the summertime marine aerosols over the Arctic Ocean, ranging from 0.017 to $0.69 \mathrm{ng} \mathrm{m}^{-3}$ with an average of $0.15 \mathrm{ng} \mathrm{m}^{-3}$. It is present in all vegetation and can be emitted into the atmosphere via biomass burning (Simoneit, 2002). $\beta$-Sitosterol was previously reported in marine aerosols from the western North Pacific during the $1991 \mathrm{El}$ Niño forest fire event that occurred in Indonesia (Kawamura et al., 2003). In general, relatively low levels of levoglucosan, dehydroabietic acid, $\beta$-sitosterol and other lignin acids indicate that the contribution of biomass burning to the summertime Arctic aerosols should be minor.

\subsubsection{Aliphatic lipids}

$n$-alkanes $\left(\mathrm{C}_{18}-\mathrm{C}_{34}\right)$ showed carbon number maxima $\left(\mathrm{C}_{\max }\right)$ at $\mathrm{C}_{27}$ with weak odd/even carbon number predominance (carbon preference index, CPI, ranging from 1.5 to 2.3), except the last sample (QFF3362) that showed CPI up to 7.0 (Table S1). CPI value is close to unity in anthropogenic sources (e.g., petroleum), while it is around 10 in terrestrial higher plant waxes. Our results demonstrate that the marine aerosols studied were mainly influenced by fossil fuel combustion except for the last sample, which was more likely affected by higher plant waxes. However, polycyclic aromatic hydrocarbons (PAHs) and hopanes, which are specific tracers for fossil fuel combustion, were not detectable in this study. Concentrations of $n$-alkanes $\left(\mathrm{C}_{18}-\mathrm{C}_{34}\right)$ ranged from 0.14 to $4.5 \mathrm{ng} \mathrm{m}^{-3}$. High molecular weight (HMW) $n$ alkanes $\left(\mathrm{C}_{25}-\mathrm{C}_{34}\right)$ were up to $3.4 \mathrm{ng} \mathrm{m}^{-3}$ in QFF3357, followed by QFF3362 $\left(0.80 \mathrm{ng} \mathrm{m}^{-3}\right)$, suggesting an input of terrestrial higher plant leaf waxes (Eglinton and Hamilton, 1967).
A homologous series of saturated fatty acids $\left(\mathrm{C}_{8}-\mathrm{C}_{32}\right)$ were detected in the samples. Except for $\mathrm{C}_{9}$, which is an oxidation product of oleic acid $\left(\mathrm{C}_{18: 1}\right)$ (Kawamura and Gagosian, 1987), a strong even carbon number predominance was observed $\left(\mathrm{CPI}=1.9-8.0\right.$ for $\left.\mathrm{C}_{20}-\mathrm{C}_{32}\right)$ with $\mathrm{C}_{\max }$ at $\mathrm{C}_{16}$ (Table $\mathrm{S} 1$ ). HMW fatty acids $\left(\geq \mathrm{C}_{24}\right)$ are derived from terrestrial higher plant waxes, while low molecular weight (LMW) fatty acids $\left(\leq \mathrm{C}_{23}\right)$ have multiple sources such as vascular plants, microbes and marine phytoplankton (Simoneit and Mazurek, 1982; Rogge et al., 1993; Kawamura et al., 2003). For example, during the MALINA campaign, Rontani et al. (2012) found that the total lipid extracts of sinking particles collected across the Canadian Beaufort shelf exhibited a distribution of even-carbon number dominated fatty acids ranging from $\mathrm{C}_{14}$ to $\mathrm{C}_{24}$. The abundances of LMW fatty acids down to $\mathrm{C}_{8}$ were found in the present study, being similar to those found in the Canadian high Arctic aerosols at Alert (Fu et al., 2009a). Such a pattern should be caused by the shift in gas/particle partitioning of LMW fatty acids due to lower ambient temperature in the Arctic than in warmer regions.

In a previous study, Fu et al. (2009a) found that alkenoic acids (e.g., $\mathrm{C}_{18: 1}$ ) were not detected in the high Arctic aerosols in winter-spring. They suggested that the Arctic aerosols were already aged during long-range atmospheric transport from middle latitudes to the Arctic. Interestingly, unsaturated fatty acids $\left(\mathrm{C}_{18: 1}\right.$ and $\left.\mathrm{C}_{18: 2}\right)$ were detected in all the marine aerosols over the Arctic Ocean in summer. They are major constituents of cell membranes in marine phytoplankton and terrestrial plants, and can emit into the atmosphere directly from leaf surfaces of plants as well as wood combustion (Fine et al., 2001). Oleic $\left(\mathrm{C}_{18: 1}\right)$ and linoleic $\left(\mathrm{C}_{18: 2}\right)$ acids are unstable and undergo photochemical degradation in the marine atmosphere (Kawamura and Gagosian, 1987), and thus have not frequently been detected in remote marine aerosols (Simoneit, 1977; Kawamura and Gagosian, 1987; Bendle et al., 2007). Bendle et al. (2007) proposed that the ratio of the unsaturated/saturated $\mathrm{C}_{18}$ fatty acids $\left(\mathrm{C}_{18: n} / \mathrm{C}_{18: 0}\right)$ could be a qualitative guide to the relative freshness of the organic matter in marine aerosol samples. Higher ratios of $\mathrm{C}_{18: n} / \mathrm{C}_{18: 0}$ were found in samples associated with proximal terrestrial inputs (QFF3362 and QFF3357, Fig. 4), while lower ratios were recorded in samples (QFF3354 and QFF3355) with air masses mainly originated from the Arctic Ocean, suggesting that the lipid compounds in the remote Arctic aerosols had longer atmospheric residence times. Such an observation was in agreement with those in marine aerosols collected in the western North $\mathrm{Pa}$ cific and Southern Ocean (Bendle et al., 2007). In addition, concentrations of linoleic acid were about ten times lower than those of oleic acid (Table S1), indicating that $\mathrm{C}_{18: 2}$ degrades more quickly than $\mathrm{C}_{18: 1}$, because polyunsaturated fatty acids are more reactive toward $\mathrm{OH}, \mathrm{NO}_{3}$ radicals and ozone. 


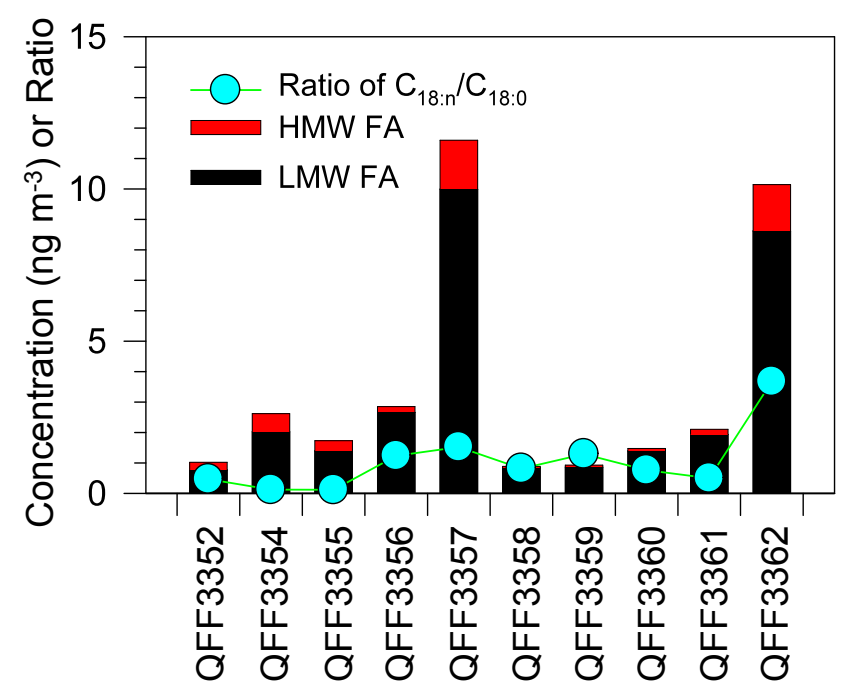

Fig. 4. Variations of high molecular weight fatty acids (HMW FA) and low molecular weight fatty acids (LMW FA) in the marine aerosols collected during the MALINA cruise. Ratios of $\mathrm{C}_{18: n} / \mathrm{C}_{18: 0}$ are present in circles.

Normal $\mathrm{C}_{12}-\mathrm{C}_{30}$ fatty alcohols were detected in the marine aerosols with a maximum at $\mathrm{C}_{14}$ or $\mathrm{C}_{16}$. Their distributions are characterized by even carbon number predominance $\left(\mathrm{CPI}=2.9-17.8\right.$ for $\left.\mathrm{C}_{20}-\mathrm{C}_{30}\right)$. Among the HMW species, $\mathrm{C}_{28}$ was the dominant species (Table S1). The homologues $<\mathrm{C}_{20}$ are abundant in soil microbes and marine biota, while the homologues $>\mathrm{C}_{24}$ are abundant in terrestrial higher plant waxes and loess deposits. Although biomass burning process can emit a large amount of fatty alcohols and fatty acids into the atmosphere (Simoneit, 2002), the contribution of biomass burning to fatty alcohols in the marine atmosphere during the MALINA campaign should be minor, a point mentioned earlier in Sect. 3.2.1. Total concentration ranges of HMW $n$-alcohols $\left(\mathrm{C}_{24}-\mathrm{C}_{30}\right)$ are $0.11-3.1 \mathrm{ng} \mathrm{m}^{-3}$ (Table 1 ), with maximum in QFF3357 and QFF3362. Similar patterns were also observed for HMW fatty acids and HMW $n$-alkanes (Table 1).

\subsubsection{Primary saccharides}

Primary saccharides consisting of glucose, fructose, sucrose, maltose and trehalose, as well as some sugar alcohols including glycerol, erythritol, arabitol, mannitol and inositol, were detected in the aerosols over the Arctic Ocean (Table S1). Their concentrations ranged from 0.91 to $112 \mathrm{ng} \mathrm{m}^{-3}$ (mean $24.5 \mathrm{ng} \mathrm{m}^{-3}$ ). They are derived from numerous sources including microorganisms, plants and animals (Simoneit et al., 2004a). They have been used as tracers for primary biological aerosol particles (Graham et al., 2003) and resuspension of surface soil and unpaved road dust (Simoneit et al., 2004a). For example, arabitol and mannitol are tracers for airborne fungal spores (Lewis and Smith, 1967; Bauer et al., 2008).

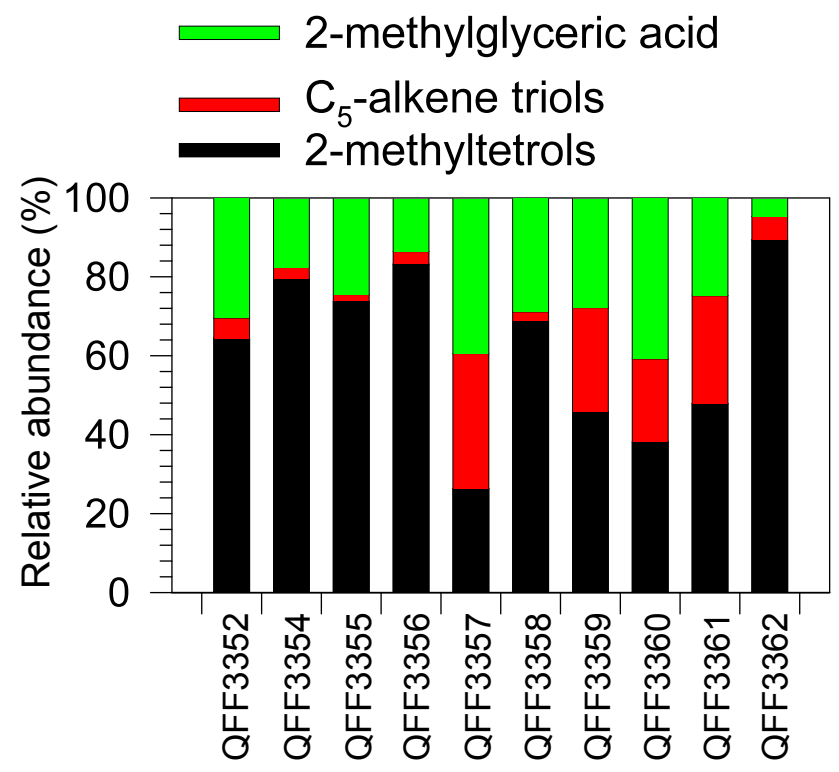

Fig. 5. Relative abundances of isoprene SOA tracers detected in the marine aerosols.

The maximum concentrations of mannitol were observed in QFF3357 and QFF3362 (Table 1). As discussed earlier, these two samples were heavily influenced by air masses from inland. In fact, mannitol was one of the most abundant compounds among all the measured organic species in the marine aerosol samples (Table S1 and Fig. 2), indicating an important contribution of terrestrial fungal spores to the summertime aerosols over the Arctic Ocean. This is reasonable because the majority of fungi have terrestrial habitats, in soils or dead plant matter, while ocean is generally a weak source of spores (Burshtein et al., 2011; Fröhlich-Nowoisky et al., 2012), although fungal spores have been reported in marine aerosols near Antarctica (Fröhlich-Nowoisky et al., 2012).

A good correlation was found between mannitol and inositol $\left(R^{2}=0.87, p<0.01\right)$ in the marine aerosols, suggesting a similar source. Ergosterol, which is a primary fungal membrane sterol and a specific biomarker for fungi (Lau et al., 2006), correlated well with mannitol $\left(R^{2}=0.96, p<0.01\right)$. Arabitol and mannitol are both considered as specific tracers for fungi (Bauer et al., 2008; Zhang et al., 2010), while a relatively weak correlation $\left(R^{2}=0.48, p<0.01\right)$ was observed between them. Different fungal species may contain different levels of arabitol and mannitol (Bauer et al., 2008). Such a weak correlation between arabitol and mannitol may imply a high diversity of fungal spores in the marine aerosols that were emitted not only from the Arctic Ocean but also from terrestrial regions through long-range atmospheric transport.

The concentrations of trehalose ranged from 0.01 to $8.7 \mathrm{ng} \mathrm{m}^{-3}$, which were higher than those (below $0.1 \mathrm{ng} \mathrm{m}^{-3}$ ) reported in the high Arctic aerosols collected in winter-spring (Fu et al., 2009a). Trehalose is present in a variety of microorganisms (fungi, bacteria and yeast), and 
Table 2. Summary of organic carbon concentrations $\left(\mu \mathrm{gC} \mathrm{m}{ }^{-3}\right)$ from biogenic primary emission (fungal-spore $\mathrm{OC}$ ) and photochemical formation (biogenic SOC) and their contributions in aerosol OC $(\%)$ in the marine aerosol samples.

\begin{tabular}{lccc}
\hline Components & range & mean & std \\
\hline Concentration $\left(\mathrm{ngC} \mathrm{m}^{-3}\right)$ & & & \\
Fungal spore OC & $0.40-407$ & 70.1 & 124 \\
Isoprene SOC & $0.80-193$ & 23.0 & 59.8 \\
$\alpha-$ Pinene SOC & $1.9-104$ & 20.8 & 38.3 \\
$\beta$-Caryophyllene SOC & $0.22-2.1$ & 0.73 & 0.64 \\
Sum of SOC & $3.7-298$ & 44.6 & 94.3 \\
Subtotal & $5.1-510$ & 115 & 186 \\
& & & \\
Percentage in aerosol OC $(\%)$ & & \\
Fungal spore OC & $0.11-26.2$ & 10.7 & 8.9 \\
Isoprene SOC & $0.41-29.8$ & 3.8 & 9.1 \\
$\alpha-$ Pinene SOC & $0.57-16.1$ & 2.9 & 4.7 \\
$\beta$-Caryophyllene SOC & $0.07-0.51$ & 0.19 & 0.13 \\
Sum of SOC in OC & $1.1-46.1$ & 6.9 & 13.8 \\
Subtotal & $1.4-64.5$ & 17.6 & 18.7 \\
\hline
\end{tabular}

a few higher plants and invertebrates (Medeiros et al., 2006). In the present study, the highest level of trehalose was found in QFF3362, which is in accordance with that of $C_{18: n} / C_{18: 0}$, indicating a fresh biogenic source. Sucrose, fructose and glucose originate from plant materials such as pollen, fruits, and their fragments (Speranza et al., 1997; Baker et al., 1998; Pacini, 2000). It should be noted that surface seawater also contains a large amount of organics, ranging from small organic acids, sugars to large molecular weight proteins, which can be emitted into the MBL through bubble bursting processes in remote oceans (Leck and Bigg, 2005; Facchini et al., 2008; Sempéré et al., 2008; Hawkins and Russell, 2010; Schmitt-Kopplin et al., 2012). However, the Beaufort Sea was oligotrophic in summer with low levels of biological activities during the MALINA cruise, which was characterized with low levels of Chl $a$ (Table 1).

\subsubsection{Phthalate esters}

Phthalate esters (phthalates) are manufactured worldwide as plasticizers and also used in cosmetics, lubricants, and other products (Thuren and Larsson, 1990). Dimethyl (DMP), diethyl (DEP), diisobutyl (DiBP), di- $n$-butyl (DnBP) and di-(2ethylhexyl) (DEHP) phthalates were detected in the marine aerosols (Table S1). Their total concentrations were 0.79 $12.4 \mathrm{ng} \mathrm{m}^{-3}\left(2.6 \mathrm{ng} \mathrm{m}^{-3}\right)$, which were higher than those reported in the North Sea to high Arctic atmosphere (0.38$1.02 \mathrm{ng} \mathrm{m}^{-3}$ ) during summer in 2004 (Xie et al., 2007). The dominant species is DEHP. This is reasonable because Xie et al. (2007) reported the particle-bound fractions of phthalates in the Arctic region during summertime increased with an increase in the molecular weight. In addition, the predom- inance of DEHP has also been reported in urban and rural aerosols in China (Wang et al., 2006). The possible source of phthalates in the Arctic troposphere may be associated with a long-range transport from mid-latitudes and the subsequent deposition on the snow/ice sheet. The high Arctic can act as a cold sink during winter. The deposited phthalates onto snow and ice can be released into the atmosphere with an increase in ambient temperature during spring-summer.

\subsubsection{Isoprene, monoterpene, and sesquiterpene SOA tracers}

Eight compounds were identified as isoprene SOA tracers in the aerosol samples, including 2-methylglyceric acid, three $\mathrm{C}_{5}$-alkene triols, two 2-methyltetrols (2methylthreitol and 2-methylerythritol), and cis- and trans-3methyltetrahydrofuran-3,4-diols (3-MeTHF-3,4-diols). Concentration ranges of 2-methylthreitol and 2-methylerythritol were $0.034-9.4 \mathrm{ng} \mathrm{m}^{-3}$ (mean $1.1 \mathrm{ng} \mathrm{m}^{-3}$ ) and 0.026 $19.0 \mathrm{ng} \mathrm{m}^{-3}\left(2.1 \mathrm{ng} \mathrm{m}^{-3}\right)$, respectively. These values are $1-3$ orders of magnitude lower than those reported in urban and forest aerosols in low to mid-latitudes (Wang et al., 2005b; Kleindienst et al., 2007; Fu et al., 2010). However, the concentrations of 2-methyltetrols in the marine aerosols collected over the Arctic Ocean in August 2009 are higher than those (mean $0.074 \mathrm{ng} \mathrm{m}^{-3}$ ) reported in Canadian high Arctic aerosols collected during winter-spring (Fu et al., 2009b), suggesting an enhanced emission of isoprene followed by photooxidation in summer. $\mathrm{C}_{5}$-alkene triols, which are reported as photooxidation products of isoprene (Wang et al., 2005b), were detected in all samples with a concentration range of $0.005-1.9 \mathrm{ng} \mathrm{m}^{-3}$ (mean $0.39 \mathrm{ng} \mathrm{m}^{-3}$ ) (Table S1). 2-Methylglyceric acid (2-MGA) is possibly formed by further oxidation of methacrolein and methacrylic acid. The concentration range of 2-methylglyceric acid in the marine aerosols was $0.064-1.8 \mathrm{ng} \mathrm{m}^{-3}\left(0.41 \mathrm{ng} \mathrm{m}^{-3}\right)$. Concentrations of 3-MeTHF-3,4-diols were estimated using a surrogate of meso-erythritol due to the lack of authentic standards; their values ranged from 0.001 to $0.070 \mathrm{ng} \mathrm{m}^{-3}\left(0.013 \mathrm{ng} \mathrm{m}^{-3}\right)$, which were much lower than that $\left(27 \mathrm{ng} \mathrm{m}^{-3}\right)$ reported in one ambient $\mathrm{PM}_{2.5}$ sample collected in Yorkville, GA, during the summer of 2010 (Lin et al., 2012).

The detected monoterpene oxidation products include pinonic acid, pinic acid, 3-hydroxyglutaric acid (3-HGA), 3-(2-hydroxyethyl)-2,2-dimethylcyclobutanecarboxylic acid (HDCCA), 3-acetylglutaric acid, 3-acetyladipic acid, 3-isopropylglutaric acid, and 3-methyl-1,2,3butanetricarboxylic acid (MBTCA). Total concentrations of monoterpene SOA tracers ranged from 0.44 to $24.1 \mathrm{ng} \mathrm{m}^{-3}$ $\left(4.8 \mathrm{ng} \mathrm{m}^{-3}\right)$ with the predominance of 3-acetyladipic acid (mean $1.5 \mathrm{ng} \mathrm{m}^{-3}$ ). The formation of MBTCA can be explained by further reaction of cis-pinonic acid with $\mathrm{OH}$ radical (Szmigielski et al., 2007). Thus it has been considered as a higher-generation product. However, MBTCA (mean $0.007 \mathrm{ng} \mathrm{m}^{-3}$ ) was found to be a minor species 
among the monoterpene SOA tracers. Such a phenomenon was previously reported in aerosols over the remote Pacific and Atlantic oceans, where MBTCA was also found to be less significant than those in the coastal aerosols (Fu et al., 2011), suggesting a relatively short atmospheric lifetime of MBTCA. $\beta$-Caryophyllinic acid, formed either by ozonolysis or photo-oxidation of $\beta$-caryophyllene (Jaoui et al., 2007), was identified in all the samples, ranging from 0.005 to $0.048 \mathrm{ng} \mathrm{m}^{-3}\left(0.017 \mathrm{ng} \mathrm{m}^{-3}\right)$.

In Figure 5, the relative abundance of isoprene SOA tracers shows that 2-methyltetrols are found as the major species in the marine aerosol samples, followed by 2-methylglyceric acid and $\mathrm{C}_{5}$-alkene triols, being similar to those in marine aerosols collected during a round-the-world cruise (Fu et al., 2011). Figure 6a-d show the variation of isoprene SOA tracers among the marine aerosol samples with obvious different patterns, which may imply their different formation processes and/or atmospheric fates. For example, chamber experiments have demonstrated that 2-methylglyceric acid is formed under high- $\mathrm{NO}_{\mathrm{x}}$ conditions, while the 2methyltetrols are mainly generated under low- $\mathrm{NO}_{\mathrm{x}}$ conditions (Surratt et al., 2006). Paulot et al. (2009) reported that gas-phase isoprene epoxydiols (IEPOX) that formed from the oxidation of isoprene hydroxyhydroperoxides (ISOPOOH) are likely to be key intermediates for isoprene SOA under low- $\mathrm{NO}_{\mathrm{x}}$ conditions. Recent studies (Surratt et al., 2010; Lin et al., 2012) have shown that IEPOX reactively uptakes onto sulfate aerosols to yield 3-MeTHF-3,4-diols, 2-methyltetrols, $\mathrm{C}_{5}$-alkene triols, dimers, and IEPOX-derived organosulfates. Recently, 3-MeTHF-3,4-diols are proposed to be formed through the acid-catalyzed intramolecular rearrangement of isoprene epoxydiols under low-NOx conditions (Lin et al., 2012).

In a previous study, the concentration ratios of $\mathrm{C}_{5}$-alkene triols to 2-methyltetrols were found to be $<0.10$ in marine aerosols over the open oceans (Fu et al., 2011), while they were much higher (up to 0.66 ) over the coastal regions such as off the California coast, in the Indian Ocean near India and the South China Sea. The lower ratios in the pristine open oceans are in agreement with the low ratios $(<0.10)$ obtained in laboratory experiments for the isoprene photooxidation in the absence of $\mathrm{NO}_{\mathrm{x}}$ (Kleindienst et al., 2009). The low ratios obtained in remote marine aerosols and the presence of $\mathrm{C}=\mathrm{C}$ bond in the structure of $\mathrm{C}_{5}$-alkene triols may suggest a significant chemical decomposition during long-range transport. In the present study, a large variation of the concentration ratios of $\mathrm{C}_{5}$-alkene triols to 2-methyltetrols $(0.02-1.3)$ was observed with the largest value of QFF3357 (Fig. 7). Surratt et al. (2010) reported that relative humidity can affect the concentration ratio of $\mathrm{C}_{5}$-alkene triols to 2-methyltetrols in the absence of $\mathrm{NO}_{\mathrm{x}}$. Although both QFF3357 and QFF3362 were collected during humid and foggy days with high levels of isoprene SOA tracer, a very low ratio was obtained for the latter sample (Fig. 7). Such a pattern is consistent with those

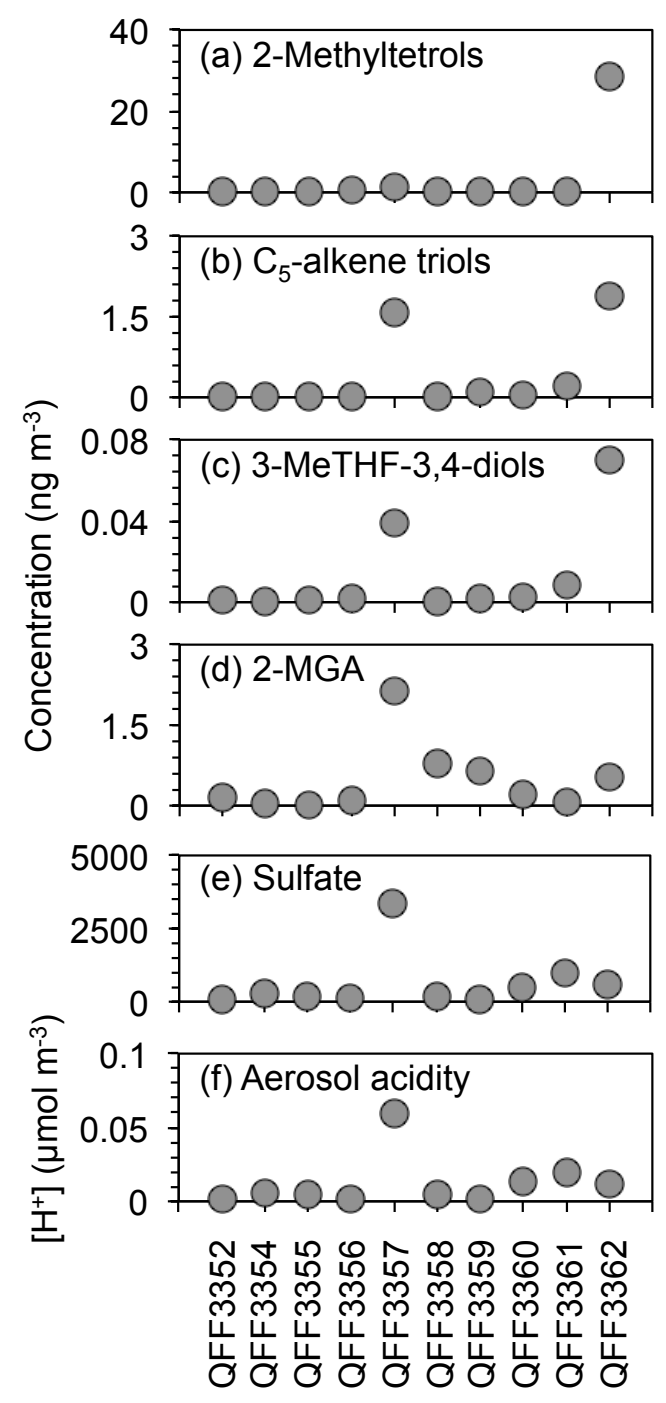

Fig. 6. Concentrations of isoprene SOA tracers and aerosol acidity measured in the marine aerosols collected over the Arctic Ocean during the MALINA campaign in August 2009.

of sulfate loading (Fig. 6e), indicating an influence of aerosol acidity.

Aerosol acidity has been reported to have significant impacts on SOA formation from the oxidation of isoprene and other biogenic VOCs (e.g., Surratt et al., 2007; Offenberg et al., 2009). In the present study, the aerosol acidity (Ziemba et al., 2007) was roughly estimated by $\left[\mathrm{H}^{+}\right]=2\left[\mathrm{SO}_{4}^{2-}\right]+$ $\left[\mathrm{NO}_{3}^{-}\right]-\left[\mathrm{NH}_{4}^{+}\right]$, where the brackets represent ion concentrations in molar units that were measured using ion chromatography (761 Compact IC, Metrohm, Switzerland). As shown in Figure 6f, the $\left[\mathrm{H}^{+}\right]$values ranged from 0.002 to $0.060 \mu \mathrm{mol} \mathrm{m}{ }^{-3}$. QFF3357 showed much stronger acidity than the other samples, which indicates that the aerosol acidity may enhance the formation of $\mathrm{C}_{5}$-alkene triols rather than 2-methyltetrols in the pristine atmosphere over the Arctic Ocean. Furthermore, aerosol acidity can favor the formation 


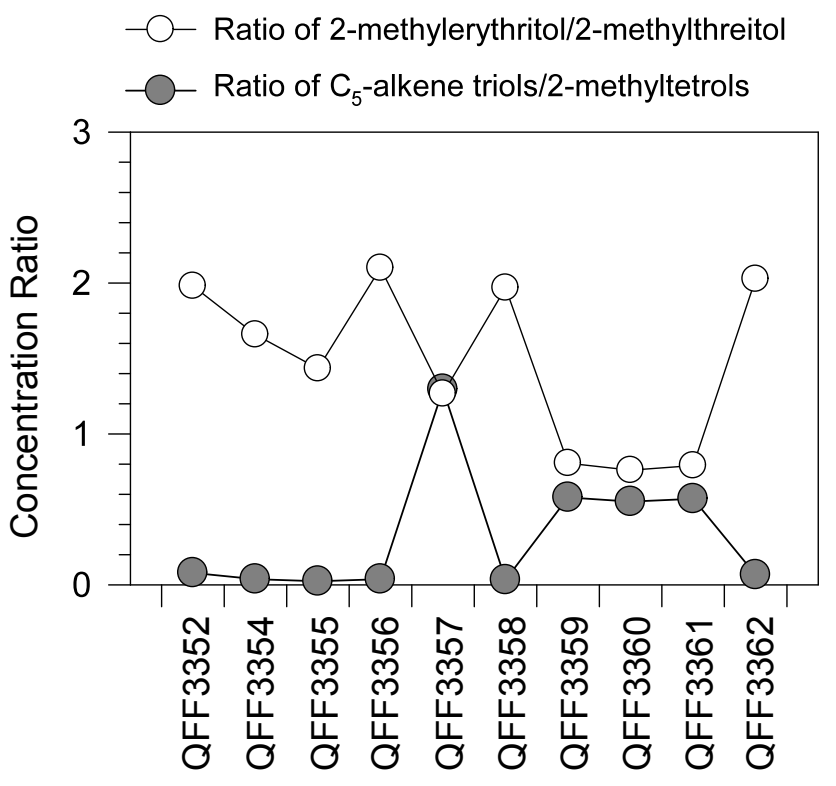

Fig. 7. Concentration ratios of isoprene SOA tracers measured in the summertime marine aerosols collected during the MALINA cruise in the Arctic Ocean.

of 3-MeTHF-3,4-diols and 2-MGA (Fig. 6c-d). Interestingly, a strong positive correlation $\left(R^{2}=0.95\right)$ was observed between 3-MeTHF-3,4-diols and $\mathrm{C}_{5}$-alkene triols (Fig. 8) in marine aerosols over the Arctic Ocean, which supports the idea that both of them can be formed through the oxidation of IEPOX under low- $\mathrm{NO}_{\mathrm{x}}$ conditions (Surratt et al., 2010; Lin et al., 2012).

Two diastereoisomeric 2-methyltetrols (2-methylthreitol and 2-methylerythritol) were first identified as oxidation products of isoprene in the Amazonian forest aerosols (Claeys et al., 2004). Since then, these organic marker compounds have been detected in ambient aerosols from different locations in the world (Hallquist et al., 2009 and references therein). Concentrations of 2-methylerythritol are generally 1.5-2.5 times more abundant than that of 2-methylthreitol in ambient aerosols (Claeys et al., 2004; Cahill et al., 2006; $\mathrm{Fu}$ et al., 2010). Interestingly, rather lower ratios of 2methylerythritol to 2-methylthreitol (down to 0.76 ) were observed in the summertime marine aerosols over the Arctic Ocean, ranging from 0.76-2.1 (Fig. 7). Such a variation indicates that the formation processes and/or the sources of the two isomers varied with time and location; this also indicates that one of the isomers may have a larger preference to atmospheric oxidative aging (i.e., heterogeneous reaction with hydroxyl radicals) during long-range transport. Another possibility is that such a difference may be due to one isomeric epoxide preferentially produced in the gas phase oxidation of isoprene (Paulot et al., 2009). In addition, Nozière et al. (2011) recently reported that 2-methyltetrols could be of biogenic origin at a certain level. A good correlation between 2-methyltetrols and sugar compounds was also reported by

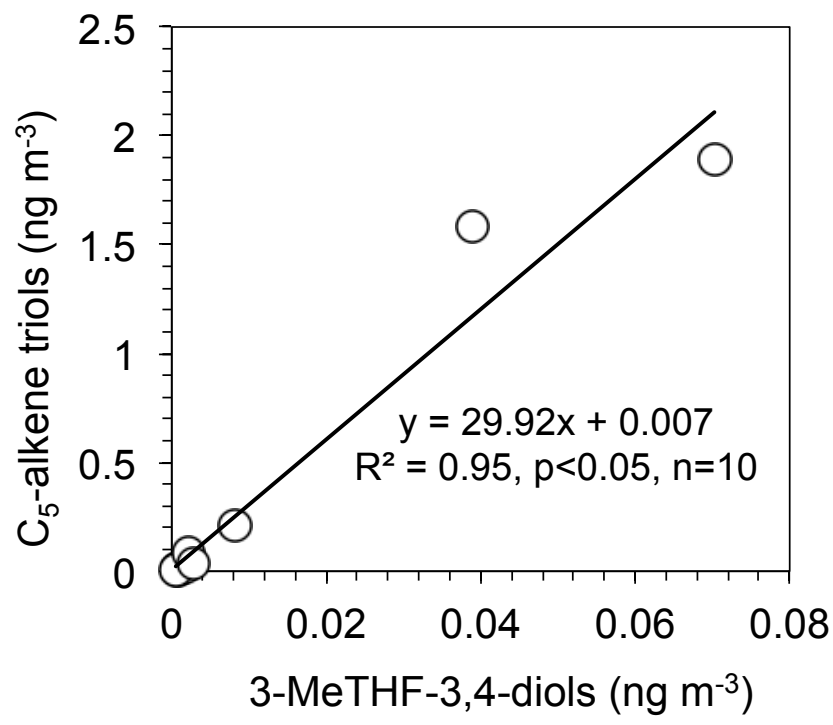

Fig. 8. Linear correlation between the concentrations of 3-MeTHF3,4-diols and $\mathrm{C}_{5}$-alkene triols measured in the summertime marine aerosols collected during the MALINA cruise.

Cahill et al. (2006), who proposed that 2-methyltetrols may arise directly from a similar biological source as sugars in addition to the well-documented photochemical pathway. Further, from Fig. 7 we can obtain an intriguing negative correlation $\left(R^{2}=0.41, p<0.01, n=10\right)$ between the concentration ratios of 2-methylerythritol to 2-methylthreitol and $\mathrm{C}_{5}$-alkene triols to 2-methyltetrols, which warrants a further study.

\subsubsection{Other polar organic acids}

Seven aromatic acids were detected in the marine aerosols, including three phthalic acids and four hydroxybenzoic acids (Table S1). Their total concentrations ranged from 0.056 to $1.8 \mathrm{ng} \mathrm{m}^{-3}\left(0.37 \mathrm{ng} \mathrm{m}^{-3}\right)$. Phthalic acids have been proposed as a surrogate for the contributions of secondary oxidation to organic aerosols, although primary sources such as biomass burning and fossil fuel combustion cannot be excluded (Kawamura and Yasui, 2005; Kundu et al., 2010). Their isomeric composition was characterized by a predominance of phthalic acid (Table S1), being consistent with those reported in continental aerosols (Wang et al., 2006).

Other hydroxy/polyacids including glycolic (hydroxyacetic acid), lactic, glyceric, malic, and tricarballylic acids were detected in the Arctic Ocean aerosols with the predominance of malic acid (Table S1). Glycolic acid is the smallest $\alpha$-hydroxy acid. It is hygroscopic and highly water-soluble. The concentration range of glycolic acid was $0.12-1.5 \mathrm{ng} \mathrm{m}^{-3}\left(0.65 \mathrm{ng} \mathrm{m}^{-3}\right)$, which was lower than those $\left(0.34-4.3 \mathrm{ng} \mathrm{m}^{-3}, 2.0 \mathrm{ng} \mathrm{m}^{-3}\right)$ in wintertime Arctic aerosols (Fu et al., 2009b). Polyacids such as malic acid are also considered as secondary oxidation products of precursor organic 
compounds. In addition, biomass burning can emit malic acid and other dicarboxylic acids and/or their precursors into the atmosphere (Kundu et al., 2010).

\subsection{Source strength of organic aerosols}

Based on previously studied emission profiles of organic compounds (Schauer et al., 1996; Simoneit et al., 2004b) and the above discussion, organic compound classes quantified in the marine aerosols from the Arctic Ocean can be roughly apportioned to five emission sources and one photooxidation product group as follows: (a) "terrestrial natural background" characterized by higher plant wax $n$-alkanes, HMW fatty acids and fatty alcohols; (b) "marine natural background" mainly reflected from LMW fatty acids, LMW fatty alcohols, and cholesterol; (c) "biomass burning" characterized by levoglucosan and its isomers, $\beta$-sitosterol, 4-hydroxybenzoic acid, and lignin/resin acids; (d) "primary biological origin" characterized by primary saccharides and reduced sugars as well as ergosterol; and (e) "photooxidation" reflected by biogenic SOA tracers, aromatic acids, and hydroxy-/polyacids. LMW dicarboxylic acids that are also of photochemical origin and abundant in atmospheric aerosols were not included in this study. According to the above-mentioned categories, all the measured organic species were converted into their carbon contents to calculate the relative abundances of each category. As shown in Fig. 9, the most abundant group was primary biological origin $(9.9-66 \%$, mean $46 \%$ ), followed by photooxidation $(9.6-40.2 \%, 21.6 \%)$, marine natural background $(8.3-34.0 \%, 16.3 \%)$, plastic emission (1.9$12.7 \%, 8.3 \%)$, biomass burning $(1.1-12.8 \%, 4.3 \%)$, and terrestrial natural background $(2.2-6.3 \%, 3.6 \%)$. Interestingly, QFF3354 obtained the highest contribution to marine natural emissions; this sample was collected during the period when the biological activity was higher than other sampling periods as seen from Chl $a$ (Table 1).

In order to obtain further information on the relative abundances of organic aerosols from primary and secondary sources, some tracer-based methods were used to estimate their contributions to aerosol OC. Here, the measured concentrations of mannitol were used to calculate the contributions of fungal spores to OC (Bauer et al., 2008). The measured biogenic SOA tracers were used to estimate the secondary organic carbon (SOC) formed from the oxidation of isoprene, $\alpha$-pinene and $\beta$-caryophyllene using a tracer-based method (Kleindienst et al., 2007). It should be noted that such estimation might suffer from a large uncertainty, a point that has been discussed in details by Yttri et al. (2011a, b) and El Haddad et al. (2011). As shown in Table 2, fungal-spore-derived OC, ranging from 0.40 to $407 \mathrm{ngC} \mathrm{m}^{-3}$, was by far the dominant source, which accounts for $0.11-26.2 \%(10.7 \%)$ of aerosol OC. For biogenic SOC, the isoprene-derived SOC $\left(0.80-193 \mathrm{ngC} \mathrm{m}^{-3}\right.$, mean $\left.23.0 \mathrm{ngC} \mathrm{m}^{-3}\right)$ was comparable with those of $\alpha$-pinene-derived SOC $\left(1.9-104 \mathrm{ngC} \mathrm{m}^{-3}\right.$,
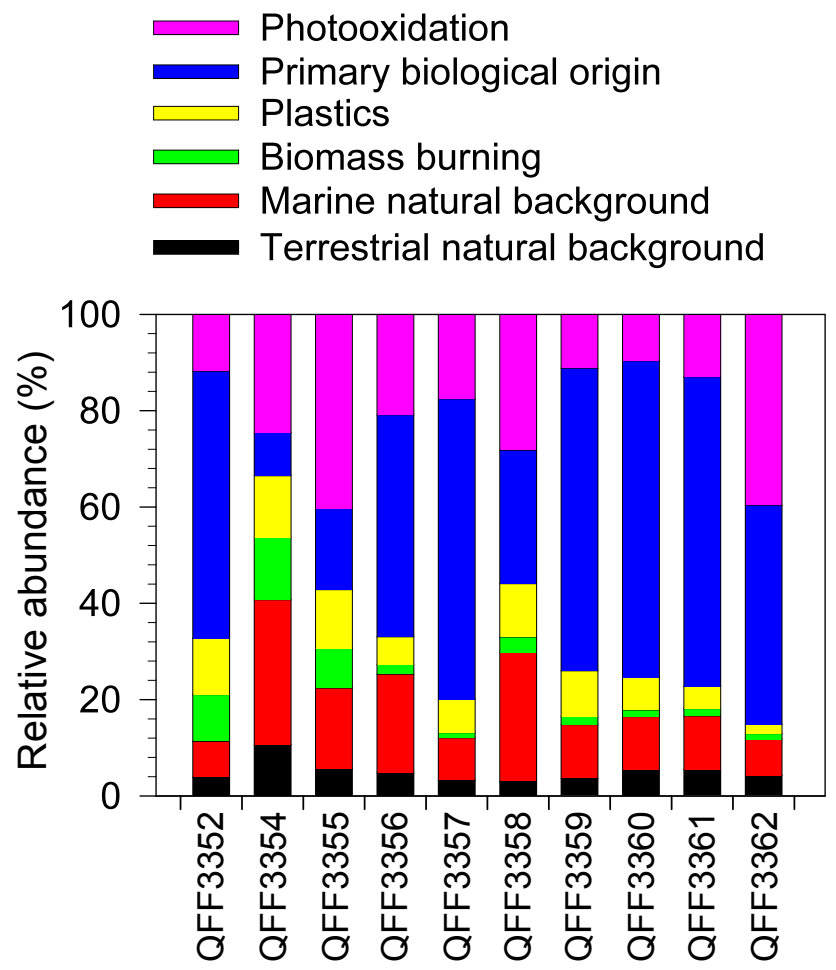

Fig. 9. Source strengths of organic species measured in the marine aerosols collected during the MALINA campaign.

$\left.20.8 \mathrm{ngC} \mathrm{m}^{-3}\right) . \beta$-Caryophyllene-derived SOC was rather minor $\left(0.22-2.1 \mathrm{ngC} \mathrm{m}^{-3}, 0.73 \mathrm{ngC} \mathrm{m}^{-3}\right)$, only accounting for $0.07-0.51 \%(0.19 \%)$ of OC. In total, these biogenic primary emission source and secondary aerosol formation can contribute $1.4-64.5 \%$ of OC with an average of $17.6 \%$. Such a low percentage suggests that the major portion of marine organic aerosols in the Arctic Ocean is still not specified at a molecular level. The unknown portion may include oligomers, organosulfates, organic nitrates, amino acids, humic-like substances, HMW organics such as proteins as well as other bioaerosols that are either from the ocean surface water through bubble bursting or from longrange atmospheric transport.

\section{Conclusions}

Ten organic compound classes were measured in marine aerosols collected in the southern Beaufort Sea, Canadian Arctic. The identified organics $\left(7.3-185 \mathrm{ng} \mathrm{m}^{-3}\right.$, $47.6 \mathrm{n} \mathrm{m}^{-3}$ ) were more abundant in the samples that were influenced by air masses from northern Canada. Distributions of biogenic SOA tracers in the marine aerosols were characterized by a predominance of isoprene and $\alpha$-pinene oxidation products, while $\beta$-caryophyllene oxidation was a minor contributor. Total measured organic species accounted for $1.8-11 \%$ (4.1\%) of OC, among which sugar compounds 
were the main contributor. By using a tracer-based method, biogenic SOC can account for 1.1-46.1\% (6.9\%) of aerosol OC. This is still lower than the contribution of fungalspore-derived OC, which on average accounted for $10.7 \%$ of aerosol OC, highlighting the importance of primary biological aerosols in the MBL over the Arctic Ocean in summer. Similarly, the results of source apportionment show that the identified organics in the MBL over the Arctic Ocean are mainly of primary biological origin, followed by secondary aerosol formation. In addition, the large variation of organic chemical composition of both primary and secondary organic aerosol tracers in different samples implies a very complex nature of marine aerosols over the Arctic Ocean. Further study is needed to characterize the seasonal variation and size distribution of organic aerosols and to better evaluate the impact of primary bioaerosols and biogenic VOCs on the aerosol chemistry in the polar regions.

\section{Supplementary material related to this article is available online at: http://www.biogeosciences.net/10/ 653/2013/bg-10-653-2013-supplement..pdf.}

Acknowledgements. This study is in part supported by the Japanese Ministry of Education, Science, Sport and Culture (grant-in-aid No. 19204055) and by the Environment Research and Technology Development Fund of the Ministry of the Environment, Japan (B-0903). P. F. appreciates the financial support from the Japan Society for the Promotion of Science (JSPS) and the Chinese National Natural Science Foundation (No. 41175106). We thank Simon Bélanger for providing the Chl $a$ data. This study was conducted as a part of the Malina Scientific Program funded by ANR (Agence nationale de la recherche), INSU-CNRS (Institut national des sciences de l'univers - Centre national de la recherche scientifique), CNES (Centre national d'études spatiales) and ESA (European Space Agency). We are grateful to M. Babin PI of the Malina Project as well as the captain and crews of the Canadian Icebreaker CCGS Amundsen. Special thanks to Julien Para for his help during the aerosol sampling.

Edited by: S. Belanger

\section{References}

Anttila, T., Langmann, B., Varghese, S., and O'Dowd, C.: Contribution of isoprene oxidation products to marine aerosol over the North-East Atlantic, Adv. Meteorol., 2010, 482603, doi:10.1155/2010/482603, 2010.

Arnold, S. R., Spracklen, D. V., Williams, J., Yassaa, N., Sciare, J., Bonsang, B., Gros, V., Peeken, I., Lewis, A. C., Alvain, S., and Moulin, C.: Evaluation of the global oceanic isoprene source and its impacts on marine organic carbon aerosol, Atmos. Chem. Phys., 9, 1253-1262, doi:10.5194/acp-9-1253-2009, 2009.
Baker, H. G., Baker, I., and Hodges, S. A.: Sugar composition of nectars and fruits consumed by birds and bats in the tropics and subtropics, Biotropica, 30, 559-586, 1998.

Barrie, L. A.: Arctic air pollution: an overview of current knowledge, Atmos. Environ., 20, 643-663, 1986.

Bauer, H., Claeys, M., Vermeylen, R., Schueller, E., Weinke, G., Berger, A., and Puxbaum, H.: Arabitol and mannitol as tracers for the quantification of airborne fungal spores, Atmos. Environ., 42, 588-593, 2008.

Bendle, J., Kawamura, K., Yamazaki, K., and Niwai, T.: Latitudinal distribution of terrestrial lipid biomarkers and $n$-alkane compound-specific stable carbon isotope ratios in the atmosphere over the western Pacific and Southern Ocean, Geochim. Cosmochim. Ac., 71, 5934-5955, 2007.

Burshtein, N., Lang-Yona, N., and Rudich, Y.: Ergosterol, arabitol and mannitol as tracers for biogenic aerosols in the eastern Mediterranean, Atmos. Chem. Phys., 11, 829-839, doi:10.5194/acp-11-829-2011, 2011.

Cahill, T. M., Seaman, V. Y., Charles, M. J., Holzinger, R., and Goldstein, A. H.: Secondary organic aerosols formed from oxidation of biogenic volatile organic compounds in the Sierra Nevada Mountains of California, J. Geophys. Res. 111, D16312, doi:10.1029/2006JD007178, 2006.

Claeys, M., Graham, B., Vas, G., Wang, W., Vermeylen, R., Pashynska, V., Cafmeyer, J., Guyon, P., Andreae, M. O., Artaxo, P., and Maenhaut, W.: Formation of secondary organic aerosols through photooxidation of isoprene, Science, 303, 1173-1176, 2004.

Claeys, M., Wang, W., Vermeylen, R., Kourtchev, I., Chi, X., Farhat, Y., Surratt, J. D., Gomez-Gonzalez, Y., Sciare, J., and Maenhaut, W.: Chemical characterization of marine aerosol at Amsterdam Island during the austral summer of 2006-2007, J. Aerosol Sci. 41, 13-22, 2010.

Eglinton, G. and Hamilton, R. J.: Leaf epicuticular waxes, Science, 156, 1322-1335, 1967.

El Haddad, I., Marchand, N., Temime-Roussel, B., Wortham, H., Piot, C., Besombes, J.-L., Baduel, C., Voisin, D., Armengaud, A., and Jaffrezo, J.-L.: Insights into the secondary fraction of the organic aerosol in a Mediterranean urban area: Marseille, Atmos. Chem. Phys., 11, 2059-2079, doi:10.5194/acp-11-20592011, 2011.

Ekström, S., Nozière, B., and Hansson, H.-C.: The Cloud Condensation Nuclei $(\mathrm{CCN})$ properties of 2-methyltetrols and C3C6 polyols from osmolality and surface tension measurements, Atmos. Chem. Phys., 9, 973-980, doi:10.5194/acp-9-973-2009, 2009.

Facchini, M. C., Rinaldi, M., Decesari, S., Carbone, C., Finessi, E., Mircea, M., Fuzzi, S., Ceburnis, D., Flagan, R., Nilsson, E. D., de Leeuw, G., Martino, M., Woeltjen, J., and O’Dowd, C. D.: Primary submicron marine aerosol dominated by insoluble organic colloids and aggregates, Geophys. Res. Lett., 35, L17814, doi:10.1029/2008GL034210, 2008.

Fine, P. M., Cass, G. R., and Simoneit, B. R. T.: Chemical characterization of fine particle emissions from fireplace combustion of woods grown in the northeastern United States, Environ. Sci. Technol., 35, 2665-2675, 2001.

Fröhlich-Nowoisky, J., Burrows, S. M., Xie, Z., Engling, G., Solomon, P. A., Fraser, M. P., Mayol-Bracero, O. L., Artaxo, P., Begerow, D., Conrad, R., Andreae, M. O., Després, V. R., and Pöschl, U.: Biogeography in the air: fungal diversity over 
land and oceans, Biogeosciences, 9, 1125-1136, doi:10.5194/bg9-1125-2012, 2012.

Fu, P. Q., Kawamura, K., and Barrie, L. A.: Photochemical and other sources of organic compounds in the Canadian high Arctic aerosol pollution during winter-spring, Environ. Sci. Technol., 43, 286-292, 2009a.

Fu, P. Q., Kawamura, K., Chen, J., and Barrie, L. A.: Isoprene, monoterpene, and sesquiterpene oxidation products in the high Arctic aerosols during late winter to early summer, Environ. Sci. Technol., 43, 4022-4028, 2009b.

Fu, P. Q., Kawamura, K., Kanaya, Y., and Wang, Z. F.: Contributions of biogenic volatile organic compounds to the formation of secondary organic aerosols over Mt. Tai, Central East China, Atmos. Environ., 44, 4817-4826, 2010.

Fu, P. Q., Kawamura, K. and Miura, K.: Molecular characterization of marine organic aerosols collected during a round-the-world cruise, J. Geophys. Res. 116, D13302, doi:10.1029/2011JD015604, 2011.

Gantt, B., Meskhidze, N., and Kamykowski, D.: A new physicallybased quantification of marine isoprene and primary organic aerosol emissions, Atmos. Chem. Phys., 9, 4915-4927, doi:10.5194/acp-9-4915-2009, 2009.

Graham, B., Guyon, P., Taylor, P. E., Artaxo, P., Maenhaut, W., Glovsky, M. M., Flagan, R. C., and Andreae, M. O.: Organic compounds present in the natural Amazonian aerosol: Characterization by gas chromatography-mass spectrometry, J. Geophys. Res. 108, 4766, doi:10.1029/2003JD003990, 2003.

Hallquist, M., Wenger, J. C., Baltensperger, U., Rudich, Y., Simpson, D., Claeys, M., Dommen, J., Donahue, N. M., George, C., Goldstein, A. H., Hamilton, J. F., Herrmann, H., Hoffmann, T., Iinuma, Y., Jang, M., Jenkin, M. E., Jimenez, J. L., Kiendler-Scharr, A., Maenhaut, W., McFiggans, G., Mentel, Th. F., Monod, A., Prévôt, A. S. H., Seinfeld, J. H., Surratt, J. D., Szmigielski, R., and Wildt, J.: The formation, properties and impact of secondary organic aerosol: current and emerging issues, Atmos. Chem. Phys., 9, 5155-5236, doi:10.5194/acp-9-51552009, 2009.

Hawkins, L. N. and Russell, L. M.: Polysaccharides, proteins, and phytoplankton fragments: Four chemically distinct types of marine primary organic aerosol classified by single particle spectromicroscopy, Adv. Meteorol., 2010, 612132, doi:10.1155/2010/612132, 2010

Hoffmann, D., Tilgner, A., Iinuma, Y., and Herrmann, H.: Atmospheric stability of levoglucosan: a detailed laboratory and modeling study, Environ. Sci. Technol., 44, 694-699, 2010.

Iziomon, M. G., Lohmann, U., and Quinn, P. K.: Summertime pollution events in the Arctic and potential implications, J. Geophys. Res. 111, D12206, doi:10.1029/2005JD006223, 2006.

Jaoui, M., Lewandowski, M., Kleindienst, T. E., Offenberg, J. H., and Edney, E. O.: $\beta$-Caryophyllinic acid: An atmospheric tracer for $\beta$-caryophyllene secondary organic aerosol, Geophys. Res. Lett., 34, L05816, doi:10.1029/2006GL028827, 2007.

Kawamura, K. and Gagosian, R. B.: Implications of $\omega$ oxocarboxylic acids in the remote marine atmosphere for photooxidation of unsaturated fatty acids, Nature, 325, 330-332, 1987.

Kawamura, K., Ishimura, Y., and Yamazaki, K.: Four years' observations of terrestrial lipid class compounds in marine aerosols from the western North Pacific, Global Biogeochem. Cycles, 17, 1003, doi:10.1029/2001GB001810, 2003.
Kawamura, K. and Yasui, O.: Diurnal changes in the distribution of dicarboxylic acids, ketocarboxylic acids and dicarbonyls in the urban Tokyo atmosphere, Atmos. Environ., 39, 1945-1960, 2005.

Kawamura, K., Ono, K., Tachibana, E., Charriére, B., and Sempéré, R.: Distributions of low molecular weight dicarboxylic acids, ketoacids and $\alpha$-dicarbonyls in the marine aerosols collected over the Arctic Ocean during late summer, Biogeosciences, 9, 47254737, doi:10.5194/bg-9-4725-2012, 2012.

Kleindienst, T. E., Jaoui, M., Lewandowski, M., Offenberg, J. H., Lewis, C. W., Bhave, P. V. and Edney, E. O.: Estimates of the contributions of biogenic and anthropogenic hydrocarbons to secondary organic aerosol at a southeastern US location, Atmos. Environ., 41, 8288-8300, 2007.

Kleindienst, T. E., Lewandowski, M., Offenberg, J. H., Jaoui, M., and Edney, E. O.: The formation of secondary organic aerosol from the isoprene $+\mathrm{OH}$ reaction in the absence of $\mathrm{NO}_{\mathrm{x}}$, Atmos. Chem. Phys., 9, 6541-6558, doi:10.5194/acp-9-6541-2009, 2009.

Kundu, S., Kawamura, K., Andreae, T. W., Hoffer, A., and Andreae, M. O.: Molecular distributions of dicarboxylic acids, ketocarboxylic acids and $\alpha$-dicarbonyls in biomass burning aerosols: implications for photochemical production and degradation in smoke layers, Atmos. Chem. Phys., 10, 2209-2225, doi:10.5194/acp-10-2209-2010, 2010.

Langmann, L., Scannell, C., and O'Dowd, C. D.: New directions: organic matter contribution to marine aerosols and cloud condensation nuclei, Atmos. Environ., 42, 7821-7822, 2008.

Lau, A. P. S., Lee, A. K. Y., Chan, C. K., and Fang, M.: Ergosterol as a biomarker for the quantification of the fungal biomass in atmospheric aerosols, Atmos. Environ., 40, 249-259, 2006.

Law, K. S. and Stohl, A.: Arctic air pollution: Origins and impacts, Science, 315, 1537-1540, 2007.

Leck, C. and Bigg, K.: Biogenic particles in the surface microlayer and overlaying atmosphere in the central Arctic Ocean during summer, Tellus, 57B, 305-316, 2005.

Lewis, D. H. and Smith, D. C.: Sugar alcohols (polyols) in fungi and green plants: 1. Distributions, physiology and metabolism, New Phytol., 66, 143-184, 1967.

Lin, Y.-H., Zhang, Z., Docherty, K. S., Zhang, H., Budisulistiorini, S. H., Rubitschun, C. L., Shaw, S. L., Knipping, E. M., Edgerton, E. S., Kleindienst, T. E., Gold, A. and Surratt, J. D.: Isoprene epoxydiols as precursors to secondary organic aerosol formation: acid-catalyzed reactive uptake studies with authentic compounds, Environ. Sci. Technol., 46, 250-258, 2012.

Medeiros, P. M., Conte, M. H., Weber, J. C. and Simoneit, B. R. T.: Sugars as source indicators of biogenic organic carbon in aerosols collected above the Howland Experimental Forest, Maine, Atmos. Environ., 40, 1694-1705, 2006.

Meskhidze, N. and Nenes, A.: Phytoplankton and cloudiness in the Southern Ocean, Science, 314, 1419-1423, 2006.

Myriokefalitakis, S., Vignati, E., Tsigaridis, K., Papadimas, C., Sciare, J., Mihalopoulos, N., Facchini, M. C., Rinaldi, M., Dentener, F. J., Ceburnis, D., Hatzianastasiou, N., O’Dowd, C. D., van Weele, M., and Kanakidou, M.: Global modeling of the oceanic source of organic aerosols, Adv. Meteorol., 2010, 939171, doi:10.1155/2010/939171, 2010.

Neusüß, C., Plewka, A., Herrmann, H., and Quinn, P. K.: Carbonaceous aerosol over the Indian Ocean: OC/EC fractions and se- 
lected specifications from size-segregated onboard samples, J. Geophys. Res. 107, 8031, doi:10.1029/2001JD000327, 2002.

Nozière, B., González, N. J. D., Borg-Karlson, A.-K., Pei, Y., Redeby, J. P., Krejci, R., Dommen, J., Prevot, A. S. H., and Anthonsen, T.: Atmospheric chemistry in stereo: A new look at secondary organic aerosols from isoprene, Geophys. Res. Lett., 38, L11807, doi:10.1029/2011GL047323, 2011.

O’Dowd, C. D., Facchini, M. C., Cavalli, F., Ceburnis, D., Mircea, M., Decesari, S., Fuzzi, S., Yoon, Y. J., and Putaud, J. P.: Biogenically driven organic contribution to marine aerosol, Nature, 431, 676-680, 2004.

O'Dowd, C. D. and de Leeuw, G.: Marine aerosol production: a review of the current knowledge, Phil. Trans. R. Soc. A, 365, 1753-1774, 2007.

Offenberg, J. H., Lewandowski, M., Edney, E. O., Kleindienst, T. E., and Jaoui, M.: Influence of aerosol acidity on the formation of secondary organic aerosol from biogenic precursor hydrocarbons, Environ. Sci. Technol., 43, 7742-7747, 2009.

Pacini, E.: From anther and pollen ripening to pollen presentation, Plant Sys. Evol., 222, 19-43, 2000.

Paris, J.-D., Stohl, A., Nédélec, P., Arshinov, M. Yu., Panchenko, M. V., Shmargunov, V. P., Law, K. S., Belan, B. D., and Ciais, P.: Wildfire smoke in the Siberian Arctic in summer: source characterization and plume evolution from airborne measurements, Atmos. Chem. Phys., 9, 9315-9327, doi:10.5194/acp-9-9315-2009, 2009.

Paulot, F., Crounse, J. D., Kjaergaard, H. G., Kurten, A., St Clair, J. M., Seinfeld, J. H., and Wennberg, P. O.: Unexpected epoxide formation in the gas-phase photooxidation of isoprene, Science, 325, 730-733, 2009.

Quinn, P. K., Shaw, G., Andrews, E., Dutton, E. G., Ruoho-Airola, T., and Gong, S. L.: Arctic haze: current trends and knowledge gaps, Tellus, 59B, 99-114, 2007.

Rinaldi, M., Decesari, S., Finessi, E., Giulianelli, L., Carbone, C., Fuzzi, S., O’Dowd, C. D., Ceburnis, D., and Facchini, M. C.: Primary and secondary organic marine aerosol and oceanic biological activity: recent results and new perspectives for future studies, Adv. Meteorol., 2010, 310682, doi:10.1155/2010/310682, 2010.

Rogge, W. F., Mazurek, M. A., Hildemann, L. M., Cass, G. R., and Simoneit, B. R. T.: Quantification of urban organic aerosols at a molecular level: Identification, abundance and seasonal variation, Atmos. Environ., Part A, 27, 1309-1330, 1993.

Rontani, J.-F., Charriere, B., Forest, A., Heussner, S., Vaultier, F., Petit, M., Delsaut, N., Fortier, L., and Sempéré, R.: Intense photooxidative degradation of planktonic and bacterial lipids in sinking particles collected with sediment traps across the Canadian Beaufort Shelf (Arctic Ocean), Biogeosciences, 9, 4787-4802, doi:10.5194/bg-9-4787-2012, 2012.

Schauer, J. J., Rogge, W. F., Hildemann, L. M., Mazurek, M. A. and Cass, G. R.: Source apportionment of airborne particulate matter using organic compounds as tracers, Atmos. Environ., 30, 38373855, 1996.

Schmitt-Kopplin, P., Liger-Belair, G., Koch, B. P., Flerus, R., Kattner, G., Harir, M., Kanawati, B., Lucio, M., Tziotis, D., Hertkorn, N., and Gebefügi, I.: Dissolved organic matter in sea spray: a transfer study from marine surface water to aerosols, Biogeosciences, 9, 1571-1582, doi:10.5194/bg-9-1571-2012, 2012 .
Sempéré, R., Tedetti, M., Panagiotopoulos, C., Charrière, B., and Van Wambeke, F.: Distribution and bacterial availability of dissolved neutral sugars in the South East Pacific, Biogeosciences, 5, 1165-1173, doi:10.5194/bg-5-1165-2008, 2008.

Simoneit, B. R. T.: Organic matter in eolian dusts over the Atlantic Ocean, Mar. Chem., 5, 443-464, 1977.

Simoneit, B. R. T. and Mazurek, M. A.: Organic matter of the troposphere-II. Natural background of biogenic lipid matter in aerosols over the rural western United States, Atmos. Environ., 16, 2139-2159, 1982.

Simoneit, B. R. T., Cardoso, J. N., and Robinson, N.: An assessment of terrestrial higher molecular weight lipid compounds in aerosol particulate matter over the south Atlantic from about $30-70^{\circ} \mathrm{S}$, Chemosphere, 23, 447-465, 1991.

Simoneit, B. R. T.: Biomass burning-a review of organic tracers for smoke from incomplete combustion, Appl. Geochem., 17, 129$162,2002$.

Simoneit, B. R. T., Elias, V. O., Kobayashi, M., Kawamura, K., Rushdi, A. I., Medeiros, P. M., Rogge, W. F., and Didyk, B. M.: Sugars-dominant water-soluble organic compounds in soils and characterization as tracers in atmospheric particulate matter, Environ. Sci. Technol., 38, 5939-5949, 2004a.

Simoneit, B. R. T., Kobayashi, M., Mochida, M., Kawamura, K., Lee, M., Lim, H. J., Turpin, B. J., and Komazaki, Y.: Composition and major sources of organic compounds of aerosol particulate matter sampled during the ACE-Asia campaign, J. Geophys. Res. 109, D19S10, doi:10.1029/2004JD004598, 2004b.

Speranza, A., Calzoni, G. L., and Pacini, E.: Occurrence of monoor disaccharides and polysaccharide reserves in mature pollen grains, Sex Plant Reprod, 10, 110-115, 1997.

Spracklen, D. V., Arnold, S. R., Sciare, J., Carslaw, K., and Pio, C.: Globally significant oceanic source of organic carbon aerosol, Geophys. Res. Lett., 35, L12811, doi:10.1029/2008GL033359, 2008.

Stohl, A., Berg, T., Burkhart, J. F., Fjae'æraa, A. M., Forster, C., Herber, A., Hov, Ø., Lunder, C., McMillan, W. W., Oltmans, S., Shiobara, M., Simpson, D., Solberg, S., Stebel, K., Ström, J., Tørseth, K., Treffeisen, R., Virkkunen, K., and Yttri, K. E.: Arctic smoke - record high air pollution levels in the European Arctic due to agricultural fires in Eastern Europe in spring 2006, Atmos. Chem. Phys., 7, 511-534, doi:10.5194/acp-7-511-2007, 2007.

Surratt, J. D., Murphy, S. M., Kroll, J. H., Ng, N. L., Hildebrandt, L., Sorooshian, A., Szmigielski, R., Vermeylen, R., Maenhaut, W., Claeys, M., Flagan, R. C. and Seinfeld, J. H.: Chemical composition of secondary organic aerosol formed from the photooxidation of isoprene, J. Phys. Chem. A, 110, 9665-9690, 2006.

Surratt, J. D., Lewandowski, M., Offenberg, J. H., Jaoui, M., Kleindienst, T. E., Edney, E. O., and Seinfeld, J. H.: Effect of acidity on secondary organic aerosol formation from isoprene, Environ. Sci. Technol., 41, 5363-5369, 2007.

Surratt, J. D., Chan, A. W. H., Eddingsaas, N. C., Chan, M. N., Loza, C. L., Kwan, A. J., Hersey, S. P., Flagan, R. C., Wennberg, P. O., and Seinfeld, J. H.: Reactive intermediates revealed in secondary organic aerosol formation from isoprene, Proc. Natl. Acad. Sci. USA, 107, 6640-6645, 2010.

Szmigielski, R., Surratt, J. D., Gómez-González, G., Van der Veken, P., Kourtchev, I., Vermeylen, R., Blockhuys, F., Jaoui, M., Kleindienst, T. E., Lewandowski, M., Offenberg, J. H., Edney, E. 
O., Seinfeld, J. H., Maenhaut, W., and Claeys, M.: 3-Methyl1,2,3-butanetricarboxylic acid: An atmospheric tracer for terpene secondary organic aerosol, Geophys. Res. Lett., 34, L24811, doi:10.1029/2007GL031338, 2007.

Thuren, A. and Larsson, P.: Phthalate esters in the Swedish atmosphere, Environ. Sci. Technol., 24, 554-559, 1990.

Wang, G. H., Kawamura, K., Lee, S., Ho, K. F., and Cao, J. J.: Molecular, seasonal, and spatial distributions of organic aerosols from fourteen Chinese cities, Environ. Sci. Technol., 40, 46194625, 2006.

Wang, H. B., Kawamura, K., and Shooter, D.: Carbonaceous and ionic components in wintertime atmospheric aerosols from two New Zealand cities: Implications for solid fuel combustion, Atmos. Environ., 39, 5865-5875, 2005a.

Wang, W., Kourtchev, I., Graham, B., Cafmeyer, J., Maenhaut, W., and Claeys, M.: Characterization of oxygenated derivatives of isoprene related to 2-methyltetrols in Amazonian aerosols using trimethylsilylation and gas chromatography/ion trap mass spectrometry, Rapid Commu. Mass Spectrom., 19, 1343-1351, 2005 b.

Xie, Z., Ebinghaus, R., Temme, C., Lohmann, R., Caba, A., and Ruck, W.: Occurrence and air-sea exchange of phthalates in the Arctic, Environ. Sci. Technol., 41, 4555-4560, 2007.

Yassaa, N., Peeken, I., Zöllner, E., Bluhm, K., Arnold, S., Sprchlen, D., and Williams, J.: Evidence for marine production of monoterpenes, Environ. Chem., 5, 391-401, 2008.
Yttri, K. E., Simpson, D., Nøjgaard, J. K., Kristensen, K., Genberg, J., Stenström, K., Swietlicki, E., Hillamo, R., Aurela, M., Bauer, H., Offenberg, J. H., Jaoui, M., Dye, C., Eckhardt, S., Burkhart, J. F., Stohl, A., and Glasius, M.: Source apportionment of the summer time carbonaceous aerosol at Nordic rural background sites, Atmos. Chem. Phys., 11, 13339-3357, doi:10.5194/acp11-13339-2011, 2011a.

Yttri, K. E., Simpson, D., Stenström, K., Puxbaum, H., and Svendby, T.: Source apportionment of the carbonaceous aerosol in Norway - quantitative estimates based on ${ }^{14} \mathrm{C}$, thermal-optical and organic tracer analysis, Atmos. Chem. Phys., 11, 9375-9394, doi:10.5194/acp-11-9375-2011, 2011 b.

Zhang, T., Engling, G., Chan, C.-Y., Zhang, Y.-N., Zhang, Z.-S., Lin, M., Sang, X.-F., Li, Y. D., and Li, Y.-S.: Contribution of fungal spores to particulate matter in a tropical rainforest, Environ. Res. Lett., 5, doi:10.1088/1748-9326/5/2/024010, 2010.

Ziemba, L. D., Fischer, E., Griffin, R. J., and Talbot, R. W.: Aerosol acidity in rural New England: Temporal trends and source region analysis, J. Geophys. Res. 112, D10SS22, doi:10.1029/2006JD007605, 2007. 